Boletín de la Sociedad Geológica Mexicana

VOLUMEN 65, NÚM. 2, 2013, P. 335-353

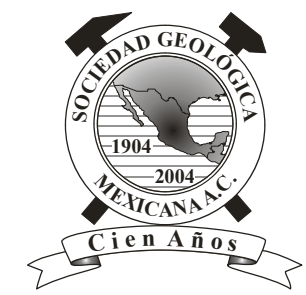

\title{
The bathyal decapod crustacean community from the Poggio i Sodi quarries (Siena Basin, Tuscany, Italy)
}

\author{
Angela Baldanza ${ }^{1}$, Roberto Bizzarri ${ }^{1}$, Federico Famiani $^{2}$, Alessandro Garassino ${ }^{3, *}$, \\ Matúš Hyžný ${ }^{4}$, Giovanni Pasini ${ }^{5}$ \\ ${ }^{1}$ Earth Science Department, Università di Perugia, Piazza Università 1, 06123 Perugia, Italy. \\ ${ }^{2}$ School of Science and Technology, Geology Division, Università di Camerino, Via Gentile III da Varano, 62032 Camerino, Italy. \\ ${ }^{3}$ Natural History Museum, Paleontology Department, Corso Venezia 55, 20121 Milan, Italy. \\ ${ }^{4}$ Department of Geology and Paleontology, Faculty of Natural Sciences, Comenius University, Mlynská dolina G1, 842 15 Bratislava, \\ Slovakia. \\ ${ }^{5}$ Via Alessandro Volta 16, 22070 Appiano Gentile (Como), Italy. \\ *alegarassino@gmail.com
}

\begin{abstract}
A rich decapod fauna from the Early Pleistocene (late Gelasian-early Calabrian) of Poggio i Sodi quarries (Siena, Tuscany, central Italy) is here reported. Integrated biostratigraphical, sedimentological and paleoecological analyses have been carried out, and some paleoenvironmental inferences are also proposed. The studied decapod community is herein assigned to the upper bathyal; several paleoenvironmental factors (cool water conditions at the sea floor, clay soft bottom, nutrients, very low environmental energy and sedimentation rate) influenced and promoted the crustacean settlement.
\end{abstract}

Keywords: Crustacea, Decapoda, Astacidea, Axiidea, Anomura, Brachyura, Early Pleistocene, Italy.

\section{Resumen}

Se reporta una fauna diversa del Pleistoceno Temprano (Gelasiano tardio-Calabriano temprano) de las canteras Poggio i Sodi (Siena, Toscana, Italia central). Se realizaron análisis integrados de bioestratigrafía, sedimentología y paleocología y algunas inferencias paleoeoambientales son propuestas. La comunidad de decápodos estudiada es aqui referida a la zona batial superior; varios factores paleoambientales (condiciones de agua fría en el fondo marino, fondo de arcilla suave, nutrientes, energía ambiental muy baja y tasa de sedimentación) influyeron y promovieron el asentamiento de los crustáceos.

Palabras Clave: Crustacea, Decapoda, Astacidea, Axiidea, Brachyura, Pleistoceno temprano, Italia.

\section{Introduction}

"Deep-water" decapod crustacean assemblages are relatively rare in the fossil record. Such reports include those by Beurlen (1939), Takeda et al. (1986), Feldmann et al. (1991), Karasawa (1991, 1993), Kato (1996) and Hyžný and Schlögl (2011). Special cases are the fossilized hydrocarbon seep and hydrothermal vent decapod associations (Bishop and Williams, 2000; Campbell, 2006; Peckmann et al., 2007; Schweitzer and Feldmann, 2008; Karasawa, 2011). Herein, we report a rich decapod fauna collected in different levels of the Poggio i Sodi area, close to Castelnuovo BerardengaScalo, east of Siena (Tuscany, central Italy). In this area several quarries cut clay and marly clay deposits for brick 
production, and the landscape is continuously modified. These deposits are already known for the rich malacofauna and fossil vertebrates (Bogi et al., 2002; Manganelli and Spadini, 2001, 2003). Among the marine vertebrates, loose teeth of the deep-water shark Clamydoselachus lawleyi (Davis, 1887) have been reported from lowermost layers of the Poggio i Sodi succession (Cigala Fulgosi et al., 2009), and an upper bathyal palaeoenvironment was inferred. Recently, De Angeli et al. (2009) have reported from the same quarry Lysirude paronae (Crema, 1895).

Since the study of the Poggio i Sodi samples has implied geological, sedimentological, systematic and palaeoenvironmental aspects, the authors of each section are designated by their initials: Angela Baldanza (A.B.), Roberto Bizzarri (R.B.), Federico Famiani (F.F.), Alessandro Garassino (A.G.), Matúš Hyžný (M.H.), and Giovanni Pasini (G.P.).

\section{Sedimentological, stratigraphical and palaeoecological framework (A.B., R.B., F.F.)}

The Castelnuovo Berardenga Scalo area is part of a wide clayey hill countryside, affected by intensive quarry activity. At present, three main quarry fronts are open along the Poggio i Sodi hill, between 220 and $280 \mathrm{~m}$ a.s.l., over an area of about $1 \mathrm{~km}^{2}$. The study area pertains to the Neogene Siena Basin (Bossio et al., 1993; Martini and Sagri, 1993; Aruta et al., 2004), and it is reconprised in the F. 297 "Asciano" (CARG Project: AA.VV., in press).

The Siena Basin (Figure 1) is a NW-SE oriented tectonic basin, bordered eastward by the Rapolano-Cetona Range and westward by the Montagnola Senese high; it accommodated a continental sedimentation during late Miocene (Messinian) time, marine deposition starting from the Early Pliocene (Zanclean), and finally renewed continental sedimentation from the Pleistocene onward. Marine deposits are mainly represented by grey-blue clay and marly clay, and are ascribed to the "Formazione delle Argille Azzurre" (FAA Fm.: Zanclean-Piacenzian). In their uppermost part, offshore marine clay deposits are laterally eteropic to nearshore sand and conglomerates ("Sabbie di S. Vivaldo", "Conglomerati di Gambassi", "Sabbie di Chiusure" formations), and are still assigned to the Zanclean-Piacenzian interval (Costantini et al., 2009; CARG Project, AA.VV., in press).

The Poggio i Sodi stratigraphic succession is still poorly studied. The most recent data are reported by Cigala Fulgosi et al. (2009), who assign the lowermost clay, containing the Chlamydoselachus lawleyi, to the late Piacenzian-earliest Gelasian stage (Late Pliocene-Early Pleistocene).

Along the northern flank of the hill, a composite section is described (figures 2,3). Deposits are mainly massive to locally laminated clay and silty clay, with local occurrence of fine sand and centimetric nodules of altered sulphides. Beds gently dip northeastward (attitude: 060/06). The whole quarry front is strongly affected by the occurrence of two main sets of sub-vertical shear planes (oriented 130-310 and 060-240 respectively), disturbing the stratigraphic continuity.

At the base, a thick shell bed occurs, prevailing Ostrea lamellosa, Venus multilamella, Cerithium sp., Anadara diluvii, Dentalium sexangulum, Dentalium rectum, Naticidae, rare solitary corals (Flabellum sp.), serpulids, and common vegetal remains. Crab remains are scattered between 235 and $260 \mathrm{~m}$ a.s.l., frequently associated with Spatangidae echinids (Figure 3).

The decapod crustaceans here described were collected over time and unfortunately the exact location of the sample is lacking. Nevertheless, the comparison between the calcareous nannofossil assemblages found on decapod samples and the new sampling data allow to relocating the decapod-bearing samples in the stratigraphic section (Figure 3).

The latter have been processed for sedimentological characterization and biostratigraphic analyses (micropalaeontological washed residues and calcareous nannofossil smear slides). The mud fraction percentages $(\varphi$ $<63 \mu \mathrm{m}$ ) are comprised between 96 and 99\%, and deposits are regarded as clay/silty clay. The sand fraction $(2 \mathrm{~mm}<\varphi$ $<63 \mu \mathrm{m}$ ) is mainly bioclastic, with rare lithics and quartz. In all fractions, abundant laminae of mica occur. Some samples contain small cylindrical pyrite concretions, black to dark brown in colour, in the range of medium sand.

The analyses of smear slides and washed residues highlight rich assemblages useful for stratigraphical assessment. The calcareous nannofossil rich assemblages, in good preservation state, are represented by small Gephyrocapsa spp. and medium Gephyrocapsa spp. (sensu Raffi, 2002), Helicosphaera sellii, Helicosphaera carteri, Coccolithus pelagicus, Calcidiscus leptoporus, rare Reticulofenestra sp., Braarudosphaera bigelowii and Pseudoemiliania lacunosa. The reworked specimens, rarely found in the assemblages, and in a poor state of preservation, are Micula sp., Discoaster broweri, Discoaster asymmetricus and Sphenolithus sp.

The presence of medium Gephyrocapsa allows identification of the MNN19 b subzone (sensu Rio et al., 1990) of the Early Pleistocene (Calabrian), and expansion of the stratigraphic documentation identified up to now for the FAA formation in the Poggio i Sodi area (ZancleanPiacenzian: Costantini et al., 2009; AA.VV., in press; late Piacenzian-earliest Gelasian: Cigala Fulgosi et al., 2009).

The washed residue analyses are in a good state of preservation and are rich in microfossil assemblages, numerically dominated by planktonic foraminifera species with low species diversity and a smaller benthic foraminifera population with high values of species diversity. Rare fragments of echinoids (mainly radioles and plaques), fish otoliths and scales are present sporadically.

Among the planktonic foraminifera the most common are Globigerinids and Neogloquadrinids, the species 


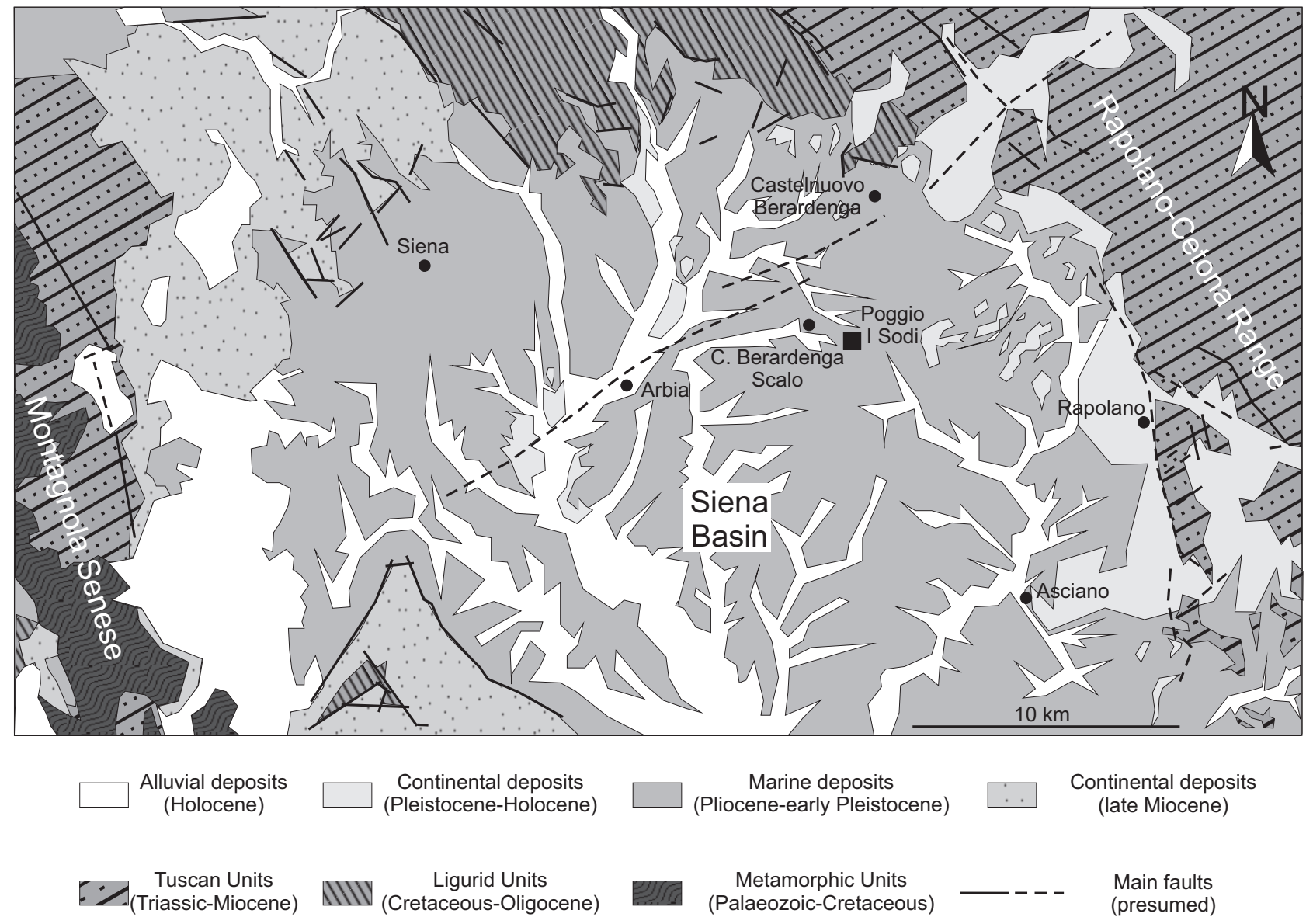

Figure 1. Simplified geological sketch for the study area (modified after Costantini et al.., 2009 and AA.VV., in press).

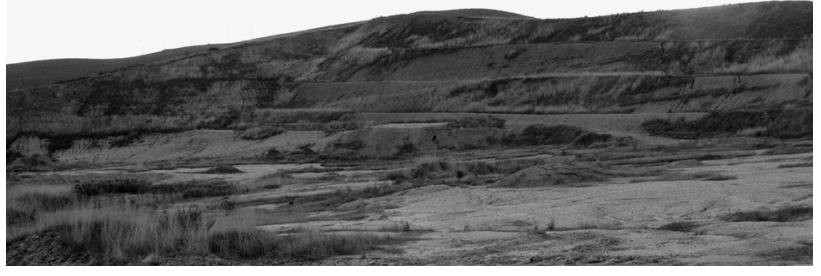

Figure 2. Panoramic view of Poggio i Sodi quarries.

Orbulina universa, Globorotalia crassaformis viola, Globigerinoides ruber and Globigerinoides sacculifer, Globorotalia apertura, Neogloboquadrina dutertrei, Globigerinella siphonifera, Neogloboquadrina pachiderma and Neogloboquadrina incompta, are present in all the assemblages. The Neogloboquadrinids species frequently occur with sinistral and dextral specimens. The species Globorotalia inflata is rarer and occurs only in a few samples.

Among the benthic foraminifera, the infaunal species such as Brizalina spathulata, Bolivina carinata, Bulimina marginata, Bulimina spinata marginata, Cassidulina carinata, Melonis padanum, Uvigerina mediterranea and
Uvigerina pygmaea are usually present in assemblages. The epifaunal benthic foraminifera are represented by Cancris auriculus, Cibicidoides ungerianus, Gyroidina altiformis, Heterolepa floridana, Hyalinea balthica, Lenticulina sp., Lobatula lobatula, Nonion depressulum, Planulina ariminensis, Quinqueloculina seminula, Spiroloculina sp. and Textularia sp. The overall presence of H. balthica is consistent with an Early Pleistocene (Calabrian) age for the study samples (Baldanza et al., 2011).

The rare ostracod fauna is characterized by Henryhowella sarsi profunda, Henryhowella sarsi sarsi, Krithe cfr. $K$. exigua, Cytherella gibba, and Xestoleberis communis. These species are all extant in the Mediterranean, except for $C$. gibba, distributed from Zanclean to Calabrian (Faranda and Gliozzi, 2008).

\subsection{Paleoenvironmental inferences}

Sedimentological features point to a low-energy sedimentary environment. The lack of lithic grains and the dominance of mud fraction are indicative of sedimentation below the storm wave base: thus, a distal and relatively deep offshore environment is inferred for Poggio i Sodi clays. According to Dunbar and Barrett (2005), a percentage 


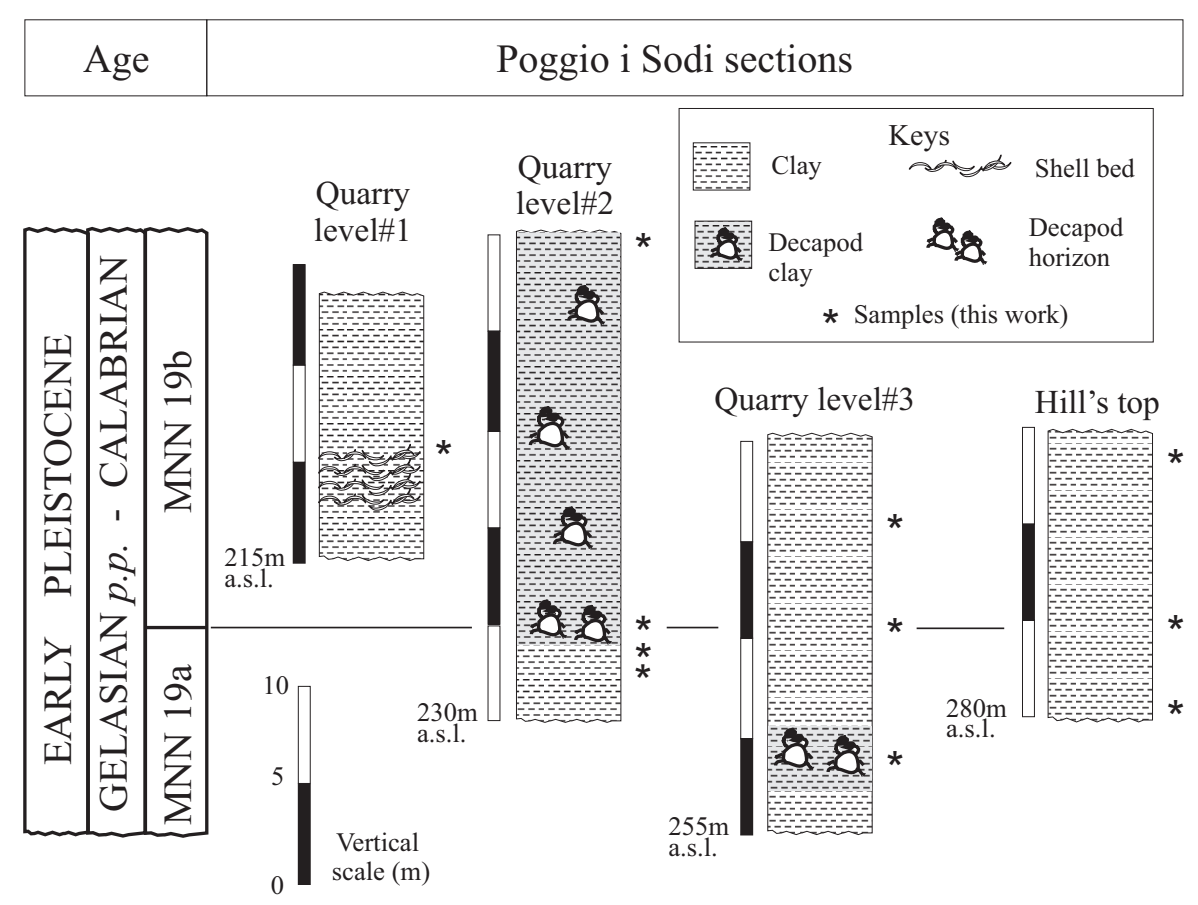

Figure 3. Composed lithostratigraphic section of Poggio i Sodi.

of fines $>80 \%$ is indicative of a minimum $60 \mathrm{~m}$ depth in wave-dominated coasts. On the other hand, nearshore deposits crop out all-around, and the emerged areas were also not so far. Clay recorded the sedimentation in the open shelf, far from the coastal influence, and an up to $200 \mathrm{~m}$ deep upper bathyal rather than abyssal environment is more likely. Sulphide nodules probably derive from the primary common occurrence of unaltered organic matter, and testify for redox conditions on the sea floor.

The benthic foraminifera assemblages and the rare ostracods lead to some important considerations about the sea floor condition as depth, temperature, nutrients, oxygen concentration and vegetation cover, following Murray (1991, 2006) and Kaiho (1999).

\subsubsection{Depth}

The benthic foraminifera assemblages contain numerous species that live in bathyal environments, such as Brizalina spathulata, Bolivina alata, Bulimina marginata, Bulimina basispinosa, Uvigerina mediterranea, and Uvigerina pygmaea. The ostracods $H$. sarsi profunda and Krithe cfr. . exigua are also assigned to an upper bathyal environment (Bonaduce et al., 1999; Sciuto and Rosso, 2008). Consequently, the decapods fauna could live in upper bathyal paleoenvironment.

\subsubsection{Temperature}

The presence in all the assemblages of several taxa (Hyalinea balthica, Lenticulina spp., Gyroidina altiformis, Cibicidoides ungerianus, Nonion depressulum and Melonis padanum) that live in cold water indicates cool conditions at the interface water-sediment. The presence of left-coiling Neogloboquadrinids, according to Serrano and GuerraMerchán (2012), also marks a sea-surface cooling trend.

\subsubsection{Nutrients}

The presence in assemblages of a well structured planktonic community, with taxa that inhabit the surficial and deep parts of photic zone, and the dominance of Neogloboquadrinids added with the abundance of phytoplankton give evidence that the water column was rich in nutrients. Moreover, the dominance of epifaunal benthic foraminifera taxa is evidence of a bottom floor rich in nutrients.

\subsubsection{Oxygen concentration}

In specific samples, the presence of infaunal taxa indicative of low oxygen content (Stefanelli, 2004), such as Cassidulina carinata, Lenticulina, Pullenia, Sphaeroidina bulloides, Uvigerina, and Valvulineria gives evidence of depletion at the sea floor. Moreover, the presence of the deep infaunal species Melonis spp. indicates that also the oxygen values are low in the bottom sediments (for almost the first $4 \mathrm{~cm}$ ).

\subsubsection{Vegetation cover}

The sea-floor was not covered by sea grass due to the cool conditions at the bottom, as evidenced by the presence of benthic foraminifera that live in cold water; the scarcity of Lobatula lobatula, characteristic epifaunal species that lives on vegetation, could be considered as reworked from shallow environments. 


\section{Material}

Twenty decapod crustaceans were studied from Poggio i Sodi quarries (Siena, Tuscany, central Italy). They were embedded in small loose blocks of grey marly clays, coming from undefined levels of the quarries. The biostratigraphic analyses of decapods-bearing blocks allow assigning all the specimens to the late Gelasian-early Calabrian interval. Crustaceans are preserved, either as slightly compressed or having a three-dimensional shape. Due to the delicate nature of the fossils and the loose matrix, all specimens were fixed with a film of polyvinyl acetate for study and preservation. The infraorder Astacidea Latreille, 1802, includes Nephrops cfr. N. norvegicus (Linnaeus, 1758) (Nephropidae Dana, 1852) (one specimen). The infraorder Axiidea de Saint Laurent, 1979, includes Bathycalliax mediterranea $\mathrm{n}$. sp. (Callianassidae Dana, 1852) (three specimens). The infraorder Anomura MacLeay, 1838, includes Galathea sp. (Galatheidae Samouelle, 1819) (one specimen). The infraorder Brachyura Linnaeus, 1758, includes Lysirude paronae (Crema, 1895) (Lyreididae Guinot, 1993) (one specimen), Calappa cfr. C. granulata (Calappidae De Haan, 1833) (one specimen), Retropluma craverii (Crema, 1895) (Retroplumidae Gill, 1894) (five specimens), Lobocarcinus sismondai (von Meyer, 1843) (Cancridae Latreille, 1802) (one specimen), Bathynectes longipes (Risso, 1816) (Polybiidae Ortmann, 1893) (three specimens), Monodaeus bortolottii Delle Cave, 1988 (Xanthidae MacLeay, 1838) (one specimen), Eriphia sp. (one specimen) (Eriphiidae MacLeay, 1838), Goneplax rhomboides (Linnaeus, 1758) (one specimen) and Albaidaplax ispalensis Garassino, Pasini and Castro, 2013 (one specimen) (Goneplacidae MacLeay, 1838). Moreover some very poorly preserved chelipeds, probably belonging to Jaxea cfr. J. nocturna (Laomediidae Borradaile, 1903), already known from the Pliocene of Tuscany, were also observed in the rich fauna but not included in this work. Finally, some well-preserved moulds of the cirolanid isopod, Palaega sismondai Ristori, 1891, have been discovered, associated with decapod crustacean community.

The specimens are deposited in the palaeontological collections of the Gruppo Paleontologico "C. De Giuli", Biblioteca Comunale Vallesiana, Castelfiorentino, Firenze (GPDG) and in the Geological Section of the Museo di Storia Naturale dell'Accademia dei Fisiocritici, Siena (MUSNAF). Compared specimens are deposited in the Museo di Storia Naturale di Milano (MSNM).

For higher-level classification, we follow the recent arrangement proposed by $\mathrm{Ng}$ et al. (2008), Baba et al. (2008), De Grave et al. (2009), and Van Bakel et al. (2012).

\section{Abbreviations}

hc: height of the carpus; hi: height of the ischium; hm: height of the merus; hpa: height of the palm; lc: length of the carpus; lexp: length of the carapace (excluding rostrum); ld: length of the dactylus; li: length of the ischium; $1 \mathrm{~m}$ : length of the merus; lpa: length of the palm; lpr: length of the propodus (including fixed finger); lr: length of the rostrum; P2-P4: pereiopods 2 to 4; s1-s6: abdominal somites 1 to 6; st4-st8: thoracic sternites 4 to 8 ; wcxp: width of the carapace.

\section{Systematic Palaeontology (A.G., M.H., G.P.)}

Order Decapoda Latreille, 1802

Infraorder Astacidea Latreille, 1802

Superfamily Nephropoidea Dana, 1852

Family Nephropidae Dana, 1852

Genus Nephrops Leach, 1814

Type species: Cancer norvegicus Linnaeus, 1758, by monotypy.

Fossil species: see Schweitzer et al. (2010).

Nephrops cfr. N. norvegicus (Linnaeus, 1758)

Figure 4.A, 4.B

Material and measurements: One single block of marly clays, including one complete propodus with major chela and minor chela in lateral view; sparse remains of the crushed carapace poorly preserved; one incomplete ambulatory leg could be assigned to palinurids (MUSNAF 7060 - major chela, ld: $51 \mathrm{~mm}$; hpa: $27 \mathrm{~mm}$; lpa: $? 60 \mathrm{~mm}$; lc: $29 \mathrm{~mm}$; lm: $42 \mathrm{~mm}$; minor chela, ld: $30 \mathrm{~mm}$; hpa: 17 $\mathrm{mm}$; ?P4, dactylus: $35 \mathrm{~mm}$; propodus: $31 \mathrm{~mm}$ ).

Description: Slender, very elongate propodus; heterochely chelae, with a strong, elongate subrectangular crushing major chela and a smaller cutting left chela; chelae with a longitudinal ridge running along the middle lower part of the palm bearing a row of robust spines and forming two broad longitudinal grooves; dorsal margin not preserved in the major chela, dentate in the minor chela, with a rim of pointed spines forward-directed; smooth lower margin; elongate dactylus and index equal in length both; pointed, curved distally with converging tips; occlusal margins with strong molariform teeth alternate with smaller ones in the major chela; reduced and more triangular in the slender minor chela; subrectangular carpus, subtriangular in cross section, with some pointed spines forward-directed along the margins; elongate, subrectangular merus, longer than the carpus with triangular spines pointed anteriorly on the distal dorsal margins; ?carapace (or parts of the body) very crushed and undeterminable; an incomplete pereiopod (P4?) with a very elongate slender pointed dactylus; elongate, subrectangular propodus and carpus, both bearing a row of strong triangular spines forward-directed along the lateral margins.

Discussion: The main characters and shape of the chelipeds of the specimen are typical of Nephropidae. 


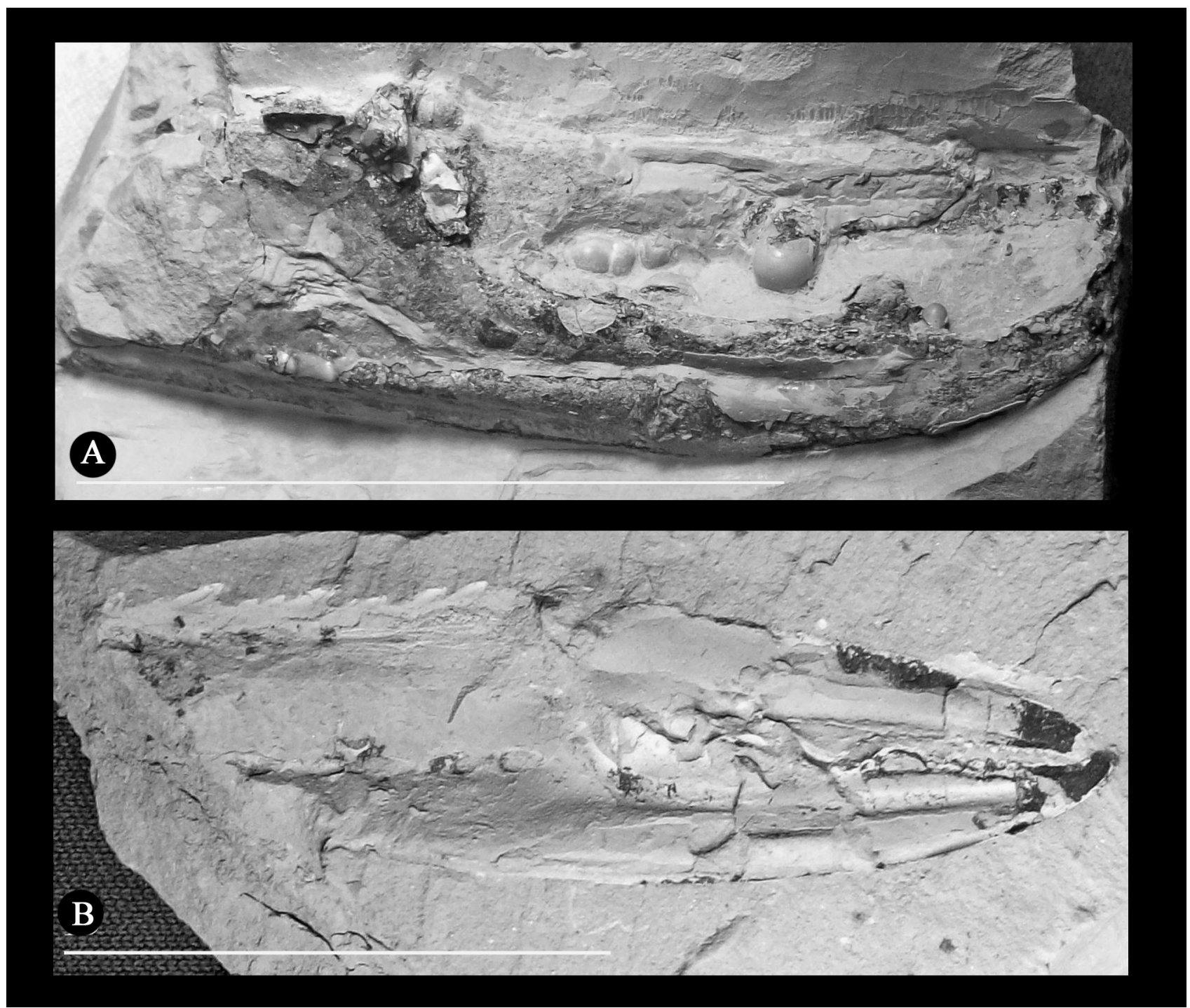

Fig. 4 - Nephrops cfr. N. norvegicus (Linnaeus, 1758), MUSNAF 7060. A) major chela, lateral view. Scale bar: 50 mm. B) minor chela, lateral view. Scale bar: $30 \mathrm{~mm}$.

Moreover, the elongate chelae with occlusal margins of the dactylus and index with strong and small molariform teeth is also a typical character of the extant and fossil Nephrops Leach, 1814. Indeed, the extant $N$. norvegicus (Linnaeus, 1758), shares some affinities with the specimen, as follows: the form and ornamentation of the heterochely chelae; the presence of molariform teeth on occlusal margins of dactylus and index of the right chela; the shape of the elongate dactylus and index gently curved distally converging at the tip; the rows of the strong pointed spines along the palms, the carpus, and the propodus; the lower median serrate ridge and the distinct longitudinal grooves along the palms of both chelae. Based upon these characteristics we ascribe the specimen to Nephrops cfr. N. norvegicus (Linnaeus, 1758), remarking on the unusually large size of the specimen if compared to an extant standard individual of this species from the Adriatic Sea (MSNM cr 2440 - total length 130 $\mathrm{mm}$, from the rostrum to the telson; major chela: $1 \mathrm{~d}: 25 \mathrm{~mm}$; hp: $12 \mathrm{~mm}$; lp: $30 \mathrm{~mm}$; lc: $15 \mathrm{~mm}$; $1 \mathrm{~m}: 25 \mathrm{~mm}$ ). This is the first report for the species in the fossil record, enlarging the knowledge on the distribution and presence of the species in the paleo-Mediterranean basin.

Finally, we point out that the single ambulatory leg strongly spinate, preserved in the same block of marly clays, does not fit into the nephropidae, having more slender and not spinate ambulatory legs, remembering instead the ornamentation of the legs representatives of the palinuridae, especially in the achelate P4. Probably this propodus and perhaps the crushed body remains do not belong to the same specimen, but they could belong to two different taxa. This chaotic assemblage might represent the remains of the feeding behaviour of an indeterminate predator that selected the softer parts of these crustacean preys (body), excluding the robust chelipeds (Nephrops) and the spinate legs (Palinuridae). 
Infraorder Axiidea de Saint Laurent, 1979

Family Callianassidae Dana, 1852

Subfamily Bathycalliacinae Sakai and Türkay, 1999

Genus Bathycalliax Sakai and Türkay, 1999

Type species: Bathycalliax geomar Sakai and Türkay, 1999, by original designation.

Fossil species: Bathycalliax mediterranea n. sp.

\section{Bathycalliax mediterranea $\mathrm{n}$. sp.}

Figures 5, 6.A-C

Diagnosis: Bathycalliax with major cheliped merus with a small distal lobe followed with a concavity on the lower margin.

Holotype: MUSNAF 7061.

Paratypes: MUSNAF 7062, 7063.

Material and measurements: One near-complete major cheliped in outer lateral view (MUSNAF 7061 hi: $5.5 \mathrm{~mm}$; li: $10.8 \mathrm{~mm}$; hm: $8.3 \mathrm{~mm}$; $1 \mathrm{~m}$ : $14 \mathrm{~mm}$; hc: not measurable; lc: $13 \mathrm{~mm}$; hpa: $17.8 \mathrm{~mm}$; lpa: $19.9 \mathrm{~mm}$; lpr: $23 \mathrm{~mm}$ ); one complete major cheliped in inner lateral view with associated minor cheliped (MUSNAF 7062 a, b - hi: $3.9 \mathrm{~mm}$; li: $10.5 \mathrm{~mm}$; hm: $5.4 \mathrm{~mm}$; lm: $11 \mathrm{~mm}$; hc: $14 \mathrm{~mm}$; lc: $12 \mathrm{~mm}$; hpa: $14.9 \mathrm{~mm}$; lpa: $14 \mathrm{~mm}$; lpr: 21.7 $\mathrm{mm}$; minor cheliped not measurable); one minor cheliped in inner lateral view (MUSNAF $7063-\mathrm{hm}: 3.3 \mathrm{~mm}$; lm: 6 $\mathrm{mm}$; hc: $6.8 \mathrm{~mm}$; lc: $6.2 \mathrm{~mm}$; hpa: $6 \mathrm{~mm}$; lpa: $6 \mathrm{~mm}$; lpr: ?11.5 mm; ld: $6.9 \mathrm{~mm}$ ).

Description: Chelipeds (first pereiopods) unequal in size and dissimilar in shape.

Major cheliped massive; ischium slender with spinulous lower margin, upper margin unarmed; merus longer than high, approximately as long as ischium, arcuate and unarmed upper margin, lower margin with small distal lobe followed with a concavity and armed with nine spines along its length, the largest being the most proximal; carpus higher than long, shorter than manus, proximolower margin regularly rounded and smooth in outline; heavy propodus, upper margin slightly converging distally, straight and smooth lower margin; index approximately half the length of manus, occlusal margin concave distally, with a large tooth positioned proximally, tip of index curved slightly upward; massive dactylus, sinuous and unarmed occlusal margin, terminated with sharp curved hook.

Minor cheliped more slender and less massive than major one; ischium not preserved sufficiently; merus with arcuate upper margin, lower margin insufficiently preserved, possibly with several spines; subtriangular carpus, approximately as long as high, proximal lower margin regularly rounded and smooth, straight upper margin; subrectangular manus, index distinctly shorter than dactylus, occlusal margin with a large blunt tooth at its base and sharp tip distally; dactylus long and slender, sinuous and unarmed occlusal margin, with blunt tip.

Other appendages, carapace and pleon preserved insufficiently or not preserved at all.

Discussion: The preservation of the material allows its assignment to Bathycalliax, which is a monotypic genus known so far only from the recent deep-water cold seeps off Oregon (Sakai and Türkay, 1999). The genus was diagnosed mainly based upon the soft part morphology as is usual for biologically defined taxa. However, the comparison of published figures (Sakai and Türkay, 1999: figs. 1-3) with other callianassid taxa allows identifying the combination of characters present on chelipeds which is unique for the genus (and its subfamily). Thus, it can be successfully used for identification of Bathycalliax in the fossil record

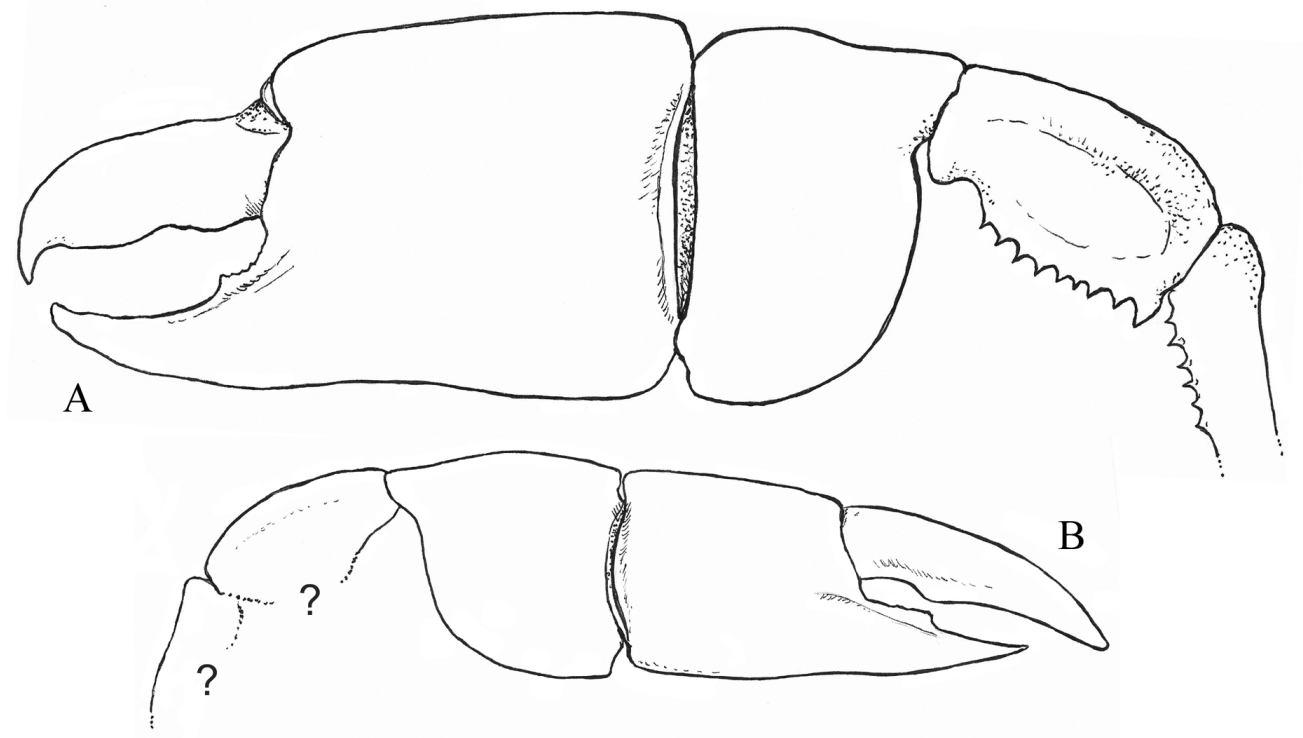

Figure 5. Bathycalliax mediterranea n. sp., reconstruction of major (A) and minor (B) chelipeds. 


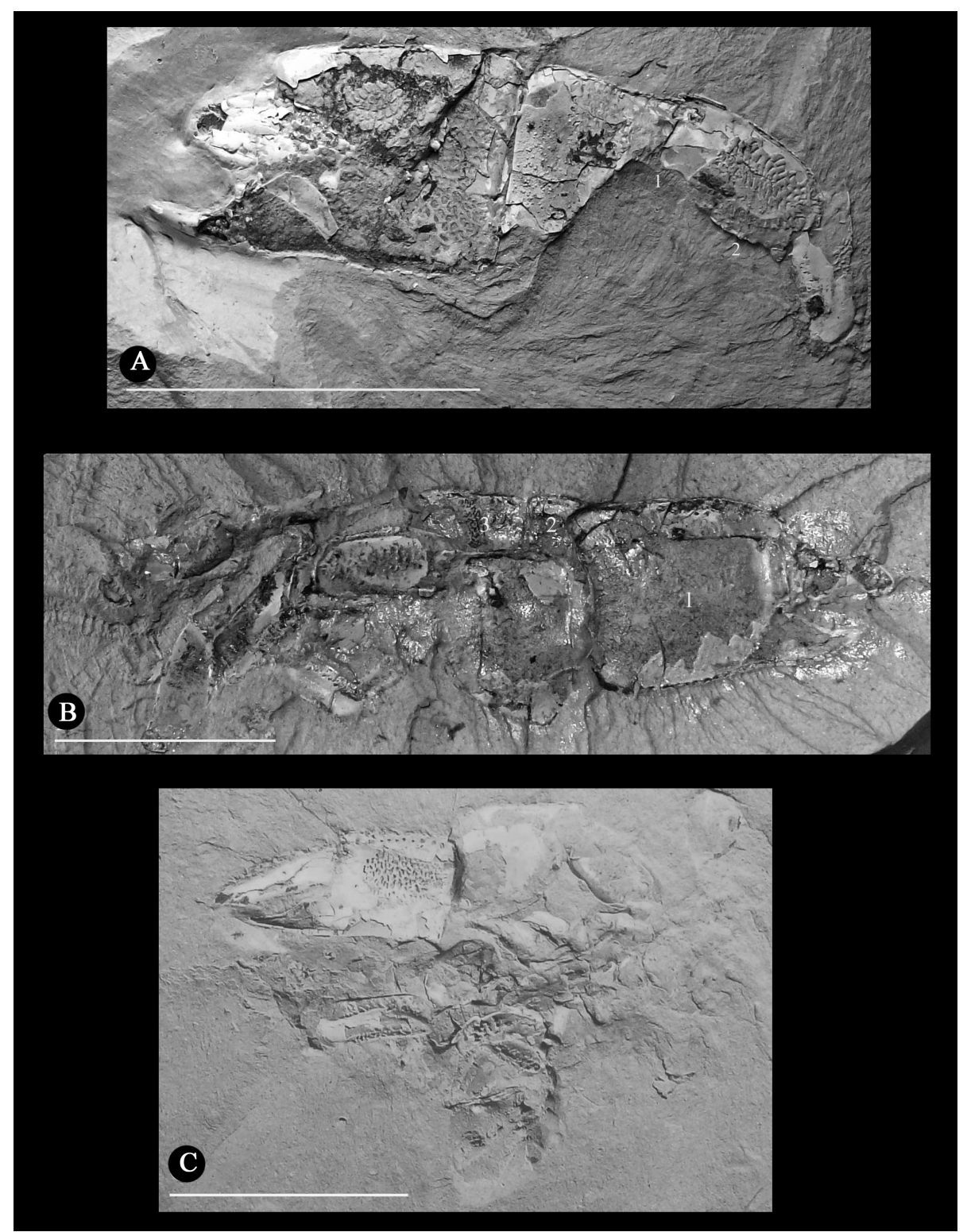

Figure 6. Bathycalliax mediterranea $\mathrm{n}$. sp., A) holotype, MUSNAF 7061, lateral view of major cheliped (1: distal meral lobe; 2: nine spines). Scale bar: $23 \mathrm{~mm}$. B) paratype, MUSNAF 7062, lateral view of major cheliped (1: major palm; 2: minor palm; 3: minor carpus). Scale bar: $21 \mathrm{~mm}$. C) paratype, MUSNAF 7063, lateral view of minor cheliped. Scale bar: $11 \mathrm{~mm}$.

where usually only chelipeds are preserved. Chelipeds of Bathycalliax are unequal in size and dissimilar in shape (Sakai and Türkay, 1999). Major cheliped of Bathycalliax typically possesses ischium and merus which have spiny lower margins. Carpus is higher than long, with the lower and proximal margins forming one single rounded edge. Propodus is rectangular with the index possessing a tooth (median triangular denticle sensu Sakai and Türkay, 1999) positioned on the midlength of its occlusal edge. The index possesses faint ridge. Dactylus has hooked tip, otherwise it is unarmed. Minor cheliped has also spiny lower margins of ischium and merus. Carpus is triangular in shape, as long as high and typically is slightly higher than propodus. The index is distinctly shorter than dactylus. All above- mentioned characters are present in our material, thus securing its generic assignment to Bathycalliax.

Several other callianassid genera possess some of the above-mentioned characters but not all of them. Glypturus Stimpson, 1866 (subfamily Callichirinae) has spiny merus, similar to Bathycalliax, but it has several spines also on the upper margin (Hyžný and Müller, 2012). Other Callichirinae taxa usually possess much longer minor cheliped carpus than Bathycalliax does and the same is true for the subfamily Callianassinae. In the nature of chelipeds, only few members of Callianassinae can be directly compared to Bathycalliax. Spiny merus is very untypical for Callianassinae. Callianassa spinophthalma Sakai, 1970, and C. intermedia Man, 1905, have such merus, but in 
other aspects are completely dissimilar to Bathycalliax. As already noted by Sakai and Türkay (1999), the subfamily Eucalliacinae seems to be close to Bathycalliax. When comparing cheliped morphology of the Eucalliacinae taxa, Calliax shows most similarities to Bathycalliax, specifically the proportions of major cheliped elements and possession of minor cheliped dactylus distinctly longer than the index (Ngoc-Ho, 2003). Calliax, however, has only a few small spines on the lower margin of merus and apart from the dactylus length, the minor cheliped is differently shaped: typically, it possesses a wide gap between fingers with a tooth forward-directed in between (see Sakai, 1999: Fig. 29C; Ngoc-Ho, 2003: Fig. 17E).

Bathycalliax mediterranea $\mathrm{n}$. sp. is very similar to the type species of Bathycalliax. The only observable difference between Bathycalliax geomar and B. mediterranea $\mathrm{n}$. sp. is a small distal lobe followed with a concavity on the lower margin of merus. Otherwise, both taxa possess the same number (9) of meral spines on its lower margin. Bathycalliax mediterranea n. sp., from the Early Pleistocene deposits of Poggio i Sodi, is the first report of Bathycalliax (and its subfamily) in the fossil record.

Infraorder Anomura MacLeay, 1838

Superfamily Galatheoidea Samouelle, 1819

Family Galatheidae Samouelle, 1819

Genus Galathea Fabricius, 1793

Type species: Cancer strigosus Linnaeus, 1761. Fossil species: see Schweitzer et al. (2010).

\section{Galathea sp.}

Figure 7

Material and measurements: One incomplete specimen in dorsal view, without rostrum (MUSNAF 7064 a, b-lcxp: $16.7 \mathrm{~mm}$; wcxp: $18 \mathrm{~mm}$ ).

Discussion: Although the rostrum is not preserved, the specimen could show affinities with Galathea affinis Ristori, 1886, as follows: the well-developed cardiac and branchiocardiac grooves, the restricted epibranchial regions weakly raised, and all regions of the carapace with continuous uninterrupted striae. Ristori (1886) described this species based upon one complete carapace from the Late Pliocene of Bianchi locality (Sicily). Later, Lörenthey (1909) reported the same species from the Miocene of Capo S. Marco (Oristano, Sardinia). A real comparison, however, with the specimen is difficult because of the loss of the holotype and additional sample. Moreover, the perfunctory description by Ristori $(1886: 126,127)$ and the poor quality of the line drawing by Ristori (1886: pl. 2, Fig. 18) do not allow establishing the peculiar diagnostic characters of G. affinis. Based upon these observations, we consider $G$. affinis a nomen dubium. Therefore, we prefer to leave the Tuscany specimen in open nomenclature, waiting for more complete material.

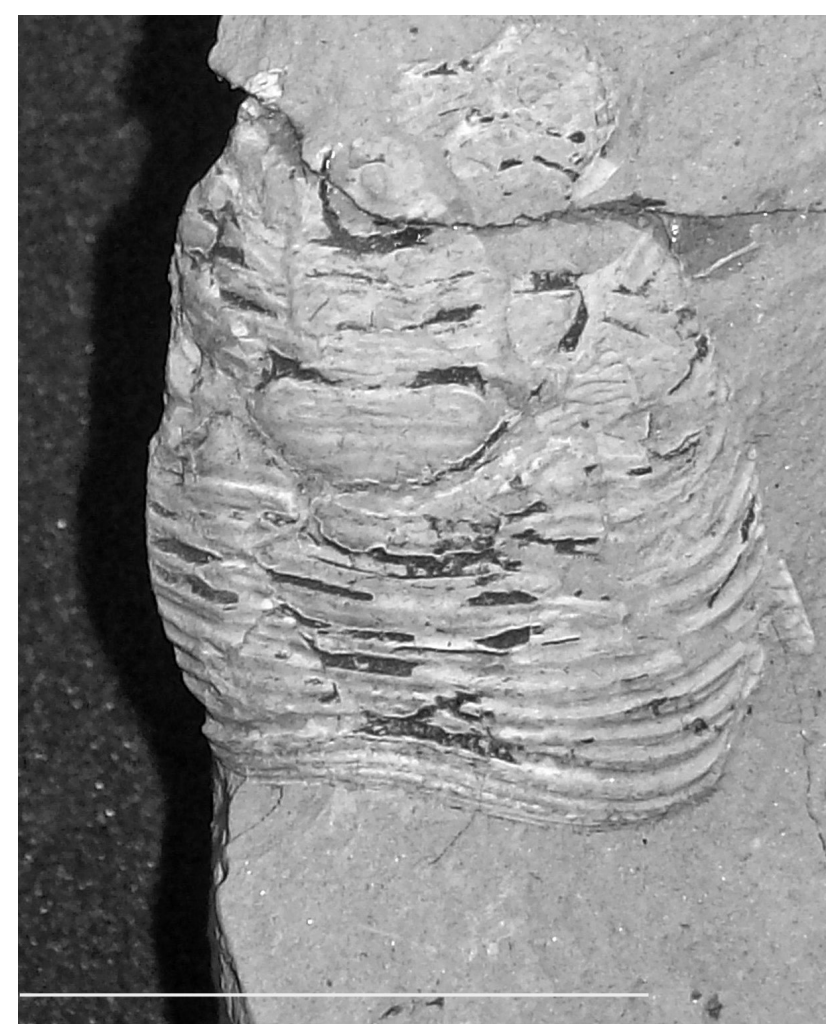

Figure 7. Galathea sp., MUSNAF 7064, dorsal view. Scale bar: $18 \mathrm{~mm}$.

Infraorder Brachyura Linnaeus, 1758

Section Podotremata Guinot, 1977

Subsection Raninoidia De Haan, 1839

Superfamily Raninoidea De Haan, 1839

Family Lyreididae Guinot, 1993

Subfamily Lyreidinae Guinot, 1993

Genus Lysirude Goeke, 1986

Type species: Lysirude nitidus (A. Milne-Edwards, 1880), by original designation.

Fossil species: see Van Bakel et al. (2012).

\section{Lysirude paronae (Crema, 1895)}

Figure 8

Lyreidus paronae Crema, 1895: 671, Fig. 11. Lysirude paronae De Angeli et al. 2009: 170, 171, Fig. 4.

Material and measurements: One nearly complete specimen in dorsal view, preserving chelipeds and ambulatory legs partially (MUSNAF $7065 \mathrm{a}, \mathrm{b}$ - lcxp: 32.7 mm; wcxp: $19.5 \mathrm{~mm}$ ).

Description: Carapace: narrow anterior margin with elongate, protruding triangular rostrum, and a pair of supraorbital spine. One extraorbital spine as long as the rostrum; elongate, divergent anterolateral margins slightly convex medially, with an oblique triangular spine pointed forward. Cheliped: flat ovoidal palm higher anteriorly, 
convex smooth dorsal margin and nearly straight ventrally; pointed index deflected downward and directed-upward distally; slender dactylus gently curved downward, with small, short, pointed teeth on occlusal margin; subrectangular carpus, with a rim of small teeth along the dorsal margin; rectangular merus, notably elongate, longer than the double of the carpus.

Discussion: The above-mentioned characters allow assigning the specimens to Lysirude paronae (Crema, 1895), already reported from the same area by De Angeli et al. (2009). This species is known from the "Helvetian" (late Miocene) of Sciolze and from the Langhian (middle Miocene) of S. Margherita (Turin) and from the Pliocene of Orta San Giulio (Novara, Piedmont) (Garassino et al., 2004).

This finding in the Early Pleistocene sediments of Poggio i Sodi increases the stratigraphical range of this genus.

Section Eubrachyura de Saint Laurent, 1980

Superfamily Calappoidea De Haan, 1833

Family Calappidae De Haan, 1833

Genus Calappa Weber, 1795

Type species: Cancer granulatus Linnaeus, 1758, subsequent designation by Latreille (1810).

Fossil species: see Schweitzer et al. (2010).

Calappa cfr. C. granulata (Linnaeus, 1758) Figure 9

Material and measurements: One left propodus in lateral view (MUSNAF $7066 \mathrm{a}, \mathrm{b}$ - ld: $6 \mathrm{~mm}$; lpa: $8 \mathrm{~mm}$; hpa: $8 \mathrm{~mm}$ ).

Description: Small left propodus strongly convex dorsally, palm higher anteriorly, with nearly straight ventral margin; dorsal margin bearing a rim of almost seven pointed acute spines. Thin, slender, pointed dactylus, nearly straight proximally, directed-downward distally.

Discussion: The above-mentioned characters are typical of the left propodus of Calappa Weber, 1795, including the extant and fossil C. granulata (Linnaeus, 1758), the only fossil species reported to date from the Pliocene of Tuscany, Piedmont, Emilia Romagna, and Sicily and from the Pleistocene of Monte Pellegrino (Sicily) (Ristori, 1891, Gemmellaro, 1914; Garassino and De Angeli, 2004; Garassino et al., 2004; De Angeli et al., 2009; Pasini and Garassino, 2013; Garassino and Pasini, 2013). Based upon the poor state of preservation of the specimen, it is prudentially compared with Calappa granulata.

\section{Superfamily Retroplumoidea Gill, 1894 \\ Family Retroplumidae Gill, 1894 \\ Genus Retropluma Gill, 1894}

Type species: Archaeoplax notopus Alcock and Anderson, 1894, by monotypy.

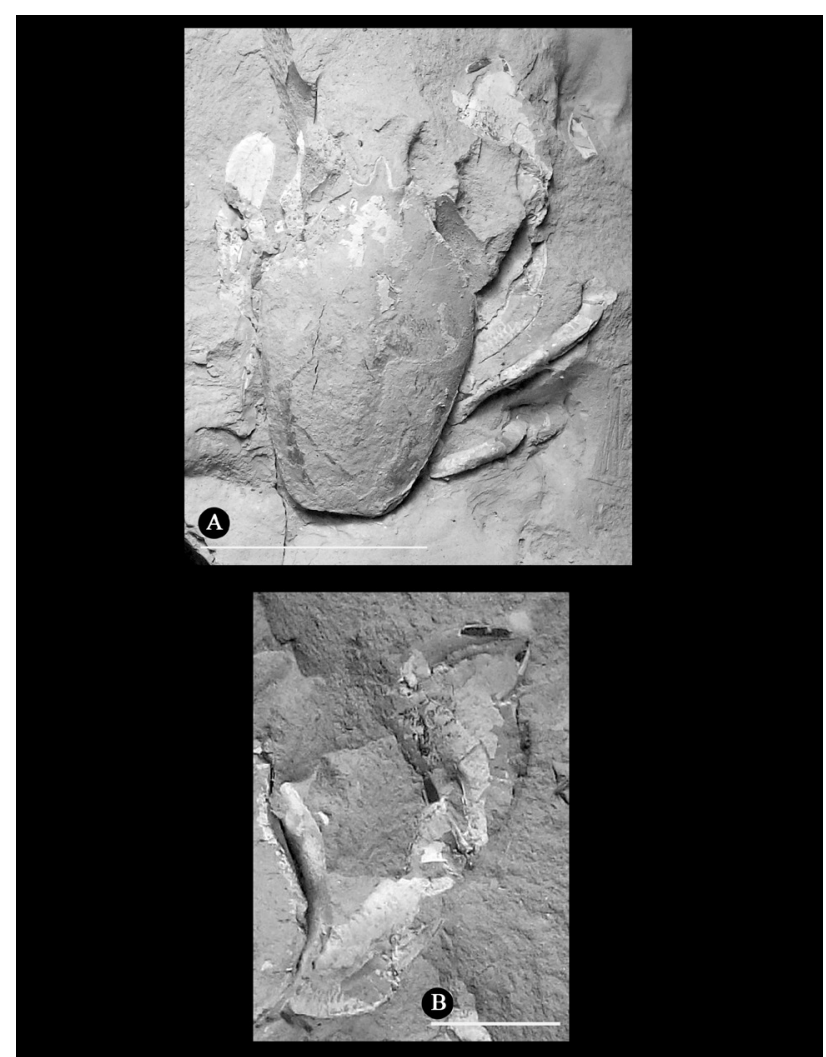

Figure 8. Lysirude paronae (Crema, 1895), MUSNAF 7065. A) dorsal view. Scale bar: $19.5 \mathrm{~mm}$. B) detail of the cheliped. Scale bar: $6 \mathrm{~mm}$.

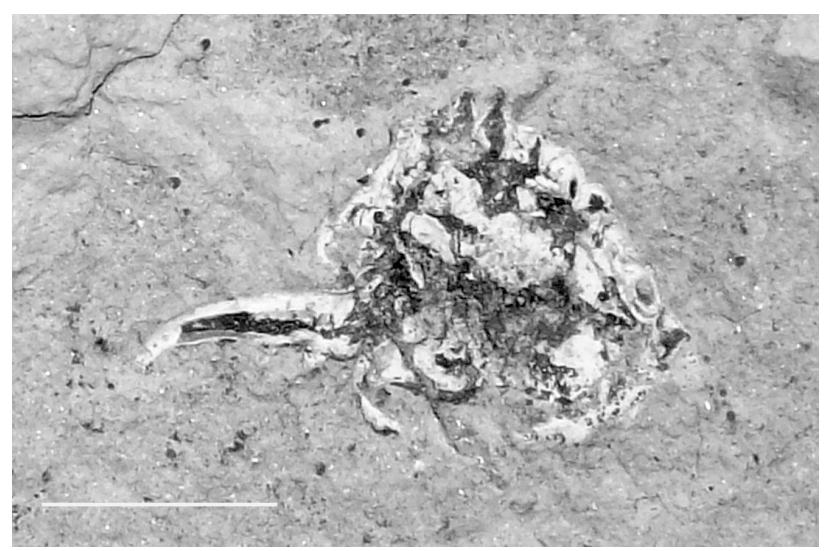

Figure 9. Calappa cfr. C. granulata (Linnaeus, 1758), MUSNAF 7066, lateral view of the chela. Scale bar: $6 \mathrm{~mm}$.

Fossil species: see Schweitzer et al. (2010).

$$
\text { Retropluma craverii (Crema, 1895) }
$$

Figure 10.A-C

Goneplax craverii Crema, 1895: 675, Fig. 16. Retropluma craverii Vía Boada, 1980: 52, 53, Fig. 1. Vía Boada, 1982: 116, Fig. 1. - De Angeli et al., 2011: 38-41, Figs. 2-4.

Material and measurements: Five specimens in dorsal 


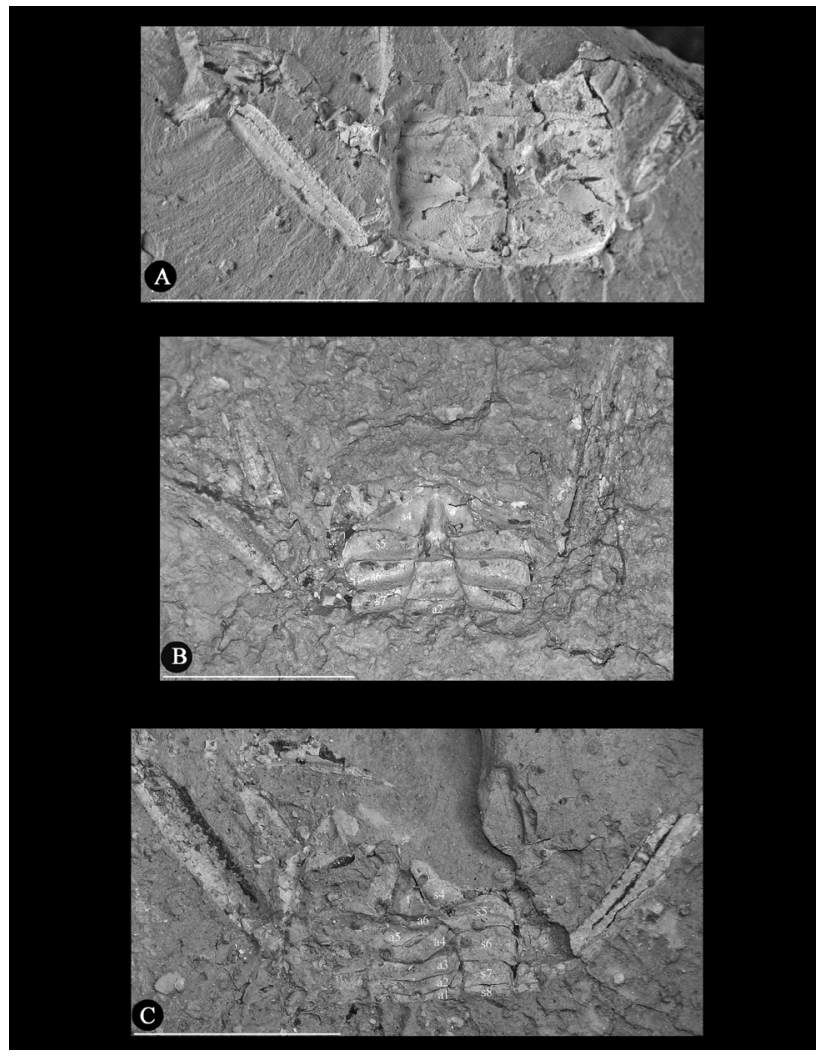

Figure 10. Retropluma craverii (Crema, 1895). A) GPDG 0225, dorsal view. Scale bar: $20 \mathrm{~mm}$. B) GPDG 0226, male ventral parts. Scale bar: $18 \mathrm{~mm}$. C) GPDG 0227, female ventral parts. Scale bar: $18 \mathrm{~mm}$. (s4-s8: sternites 4-8; a1-a6: pleonal somites 1-6; t: telson).

and ventral views (GPDG 0223 - lcxp: $4.6 \mathrm{~mm}$; 1r: $0.5 \mathrm{~mm}$; wcxp: $6 \mathrm{~mm}$; GPDG 0224 - lcxp: $13 \mathrm{~mm}$; lr: $1.5 \mathrm{~mm}$; wcxp: $18.3 \mathrm{~mm}$; GPDG 0225 - lexp: $20 \mathrm{~mm}$; lr: $2.5 \mathrm{~mm}$; wexp: $24.5 \mathrm{~mm}$; GPDG 0226, 0227 not measurable).

Description: Carapace: subrectangular carapace, weakly convex longitudinally, wider than long, almost flat in transverse section; very elongate, narrow, cylindrical rostrum slightly spatulated in the proximal part; broad, sinuous supraorbital margin, with small supraorbital projection; postorbital tooth well developed, forwardly directed; short anterolateral margin slightly concave; smooth frontal margin and lateral margins; posterolateral margin considerably longer and arched; gently rounded, rimmed posterior margin distinctly broader than the orbitofrontal margin; dorsal surface of carapace with three sharp-crested, smooth transverse ridges; continuous, straight anterior ridge, parallel to anterior margin, crossing the entire dorsal surface; median transverse ridge slightly inclined, well developed at the lateral flanks only, interrupted at level of urogastric region; continuous, straight posterior ridge, parallel to the anterior one, located in the posterior region; dorsal surface of carapace covered with delicate, small granules uniformly distributed; regions of carapace weakly marked; weak cervical groove, located between anterior and median ridges, separating gastric regions from branchial ones; distal part of cervical groove ornamented with a ridge of small aligned tubercles. Mesogastric region with two blunt tubercles. Thoracic sternum subtriangular anteriorly in both sexes, rounded at the tip, enlarging abruptly posteriorly, specially in female; deep sternal cavity in male; wide triangular st4 with a deep lateral concave sinus at the first coxa joint, ending anteriorly with a rounded triangular tooth forwardly directed (in male); petaloid st5-st7 in both sexes, slightly shorter and higher in female, each bearing a granulate, transverse, sinuous ridge posteriorly; st 8 very reduced, poorly preserved. - Male pleon: subtrapezoidal pleonal somites, with smooth, median, longitudinal, granulate ridge; s3-s4 and s5? fused; triangular telson, elongate, rounded anteriorly; pleonal shield outline slightly concave laterally. - Female pleon: subrectangular s1-s6 frees, articulated and wider than male, decreasing anteriorly, laterally convex, with concave posterior margin; a very weak median transverse ridge present in s1-s6; s1 reduced; triangular telson wider than male. - Thoracic appendages: chelipeds with elongate merus, short, subtriangular carpus, propodus ventrally flatted; elongate subrectangular chelae shorter in male, rounded dorsally, with slender elongate pointed dactyli; dactylus gently curved distally; index straight ventrally, slightly curved distally; index longer than palm in female; occlusal margins nearly smooth; P2-P4 slender, notably elongate, flattened laterally, granulate dorsally and ventrally, with a smooth depressed longitudinal median ridge; P3 longer than P2, both slightly longer than P4.

Discussion: Usually the fossil record of Retroplumidae from the Pliocene of Italy is rare. Indeed this family was known to date only with two genera, Bathypluma (de Saint Laurent, 1989) from Tuscany (central Italy) (Garassino et al., 2012) and Retropluma (Gill, 1894) from Piedmont and Emilia Romagna (N Italy). The last one is known by the only Retropluma craverii, described for the first time by Crema (1895) from the Late Pliocene (Piacenzian) of Bra (Piedmont, N Italy). De Angeli et al. (2011) revised Retropluma craverii by two retroplumids from the Pliocene of Reggio Emilia (northern Italy), with a well-preserved pleon that allows describing morphological characters of the sternum and pleon in both sexes, and identifying some morphological characters, such as the very elongate and narrow rostrum, the wide orbitofrontal margin distinctly sinuous, ending with a well-developed tooth forwardly directed, and the dorsal surface of the carapace with three transverse ridges, similar to those of the specimens that are assigned to $R$. craverii.

The report of this species from the Early Pleistocene of Tuscany further enlarges its geological range and geographical distribution southwards, in the paleoMediterranean basin, pointing out the paleo-biostratigraphic problem in the reconstruction of the fossil distribution of Retroplumidae, as already reported by de Saint Laurent (1989, p. 150). 
Superfamily Cancroidea Latreille, 1802

Family Cancridae Latreille, 1802

Subfamily Lobocarcininae Beurlen, 1930

Genus Lobocarcinus Reuss, 1857

Type species: Cancer paulino-würtembergensis von Meyer, 1847, by original designation.

Fossil species: see Schweitzer et al. (2010).

Lobocarcinus sismondai (von Meyer, 1843)

Figure 11

Cancer Sismondae von Meyer, 1843, p. 590.

Cancer punctulatus Desmarest, 1822, p. 92, pl. 7, figs. 3-4.

Platycarcinus antiquus Sismonda, 1846, p. 58-60, pl. 3,

figs. 1, 2. - Meneghini, 1857, p. 528, pl. H, fig. 11.

Platycarcinus sismondai Vinassa de Regny, 1896, p. 124127, pl. 2, fig. $1 \mathrm{a}, \mathrm{b}$.

Cancer deshayesii A. Milne-Edwards, 1864, p. 314, pl. 22, figs. 1, 2, pl. 23, fig. 1. - Couffon, 1908, p. 5, pl. 2, fig. 11. -Van Straelen, 1927, p. 87, pl. 3, Ffig. 2, pl. 4, figs. $1,2$.

Cancer sismondai A. Milne-Edwards, 1864, p. 316, pls. 24, 25. - Ristori, 1886, p. 95-99, pl. 2, fig. 1. - Varola, 1981, p. 16-26, pl. 3, figs. 5, 6, pl. 4, figs. 1, 2, pl. 5, figs. 1, 2, pl. 6, figs. 2, 4. - Bonfiglio and Donadeo, 1982, p. 270-291, figs. 5-27, pls. 33-44. - Bonfiglio, 1982, p. 5-18, figs. 1-4, pls. 1-7. - Moisette and Müller, 1990, p. 739, 740, pl. 1, Ffig. 1, pl. 2, figs. 1, 2. - Beschin and Santi, 1997, p. 13, fig. 2, pl. 1, figs. 1, 2. - Garassino and Fornaciari, 2000, p. 29, fig. 1.

Lobocarcinus sismondai Reuss, 1858, p. 41, pl. 9, figs. 1, 2. - Garassino and De Angeli, 2004, p. 42, 43, figs. 9-11. Lobocarcinus imperator Reuss, 1858, p. 41, pls. 7, 8, pl. 9, fig. 1.

Cancer sismondai var. antiatina Maxia, 1946, p. 134-147, fig. 1, pl. 1, figs. 2-5.

Material and measurements: One incomplete specimen in dorsal view (MUSNAF 7067 a, b - lexp: 116 mm; wcxp: $61 \mathrm{~mm}$ ).

Discussion: The presence of three-fid front, the orbits very close, the anterolateral margin with ten spiny lobes, the posterolateral margin with a series of tubercles, and the dorsal surface of the carapace with well-marked grooves allow assigning the specimen to Lobocarcinus sismondai (von Meyer, 1843). This species is widely spread in the fossil record from the Miocene to the Pleistocene of Italy (Piedmont, Emilia Romagna, Lazio, Puglia, Calabria, Sardinia, Sicily) and Europe (Great Britain, the Netherlands, Spain, Hungary, Greece, Austria), and Algeria (see De Angeli and Garassino, 2006 for references). This is the first report of this species from the Early Pleistocene of Tuscany. As already pointed out by Fornaciari and Garassino (1996), the presence of this species from the Pleistocene of Italy questions the real systematic validity

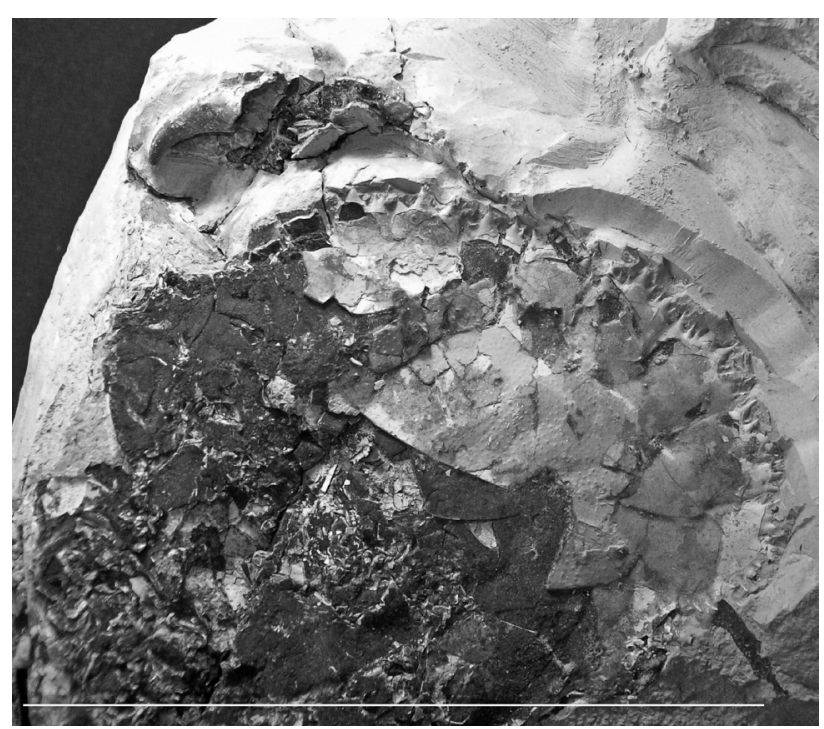

Figure 11. Lobocarcinus sismondai (von Meyer, 1843), MUSNAF 7067, dorsal view. Scale bar: $61 \mathrm{~mm}$.

of the extant Cancer bellianus Johnson, 1861, widespread in the Mediterranean Sea and Atlantic Ocean (Falciai and Minervini, 1992; Zariquiey Álvarez, 1968). Indeed, the fossil and extant species share numerous morphological characters, such as the shape of the carapace, the shape and distribution of the dorsal areas of the carapace, the number of the spiny lobes in the anterolateral margins (each lobe armed with three teeth, of which the middle one is larger), the posterolateral margin with a series of tubercles, the shape and location of the eyes, and the shape and ornamentation of the chelipeds (Johnson, 1861). Further re-evaluation of both taxa L. sismondai and C. bellianus is needed to resolve this taxonomic bias.

\section{Superfamily Portunoidea Rafinesque, 1815 \\ Family Polybiidae Ortmann, 1893 \\ Genus Bathynectes Stimpson, 1871}

Type species: Bathynectes longispina Stimpson, 1871, by subsequent designation by Fowler (1912).

Fossil species: Bathynectes muelleri Ossó and Stalennuy, 2011.

\section{Bathynectes longipes (Risso, 1816) Figure 12}

Portunus longipes Risso, 1816: , p. 30, pl. 1, fig. 5. Bathynectes longipes Lebour, 1928, p. 516, pl. 4, fig. 7.- Lebour, 1931, p. 93, pl. 1, fig. 1.- Bouvier, 1940, p. 246, fig. 158, pl. 9, fig. 12. - Nobre, 1936, p. 40, pl. 15, fig. 36.-Zariquey Álvarez, 1946, p. 158, pl. 15, fig. a. - Zariquey Álvarez, 1968, 392, figs. 14e, 122a, 125b, c, 126b, 127e, f. - Ossó and Stalennuy, 2011, p. 41, 44, fig. 8.1-5. 


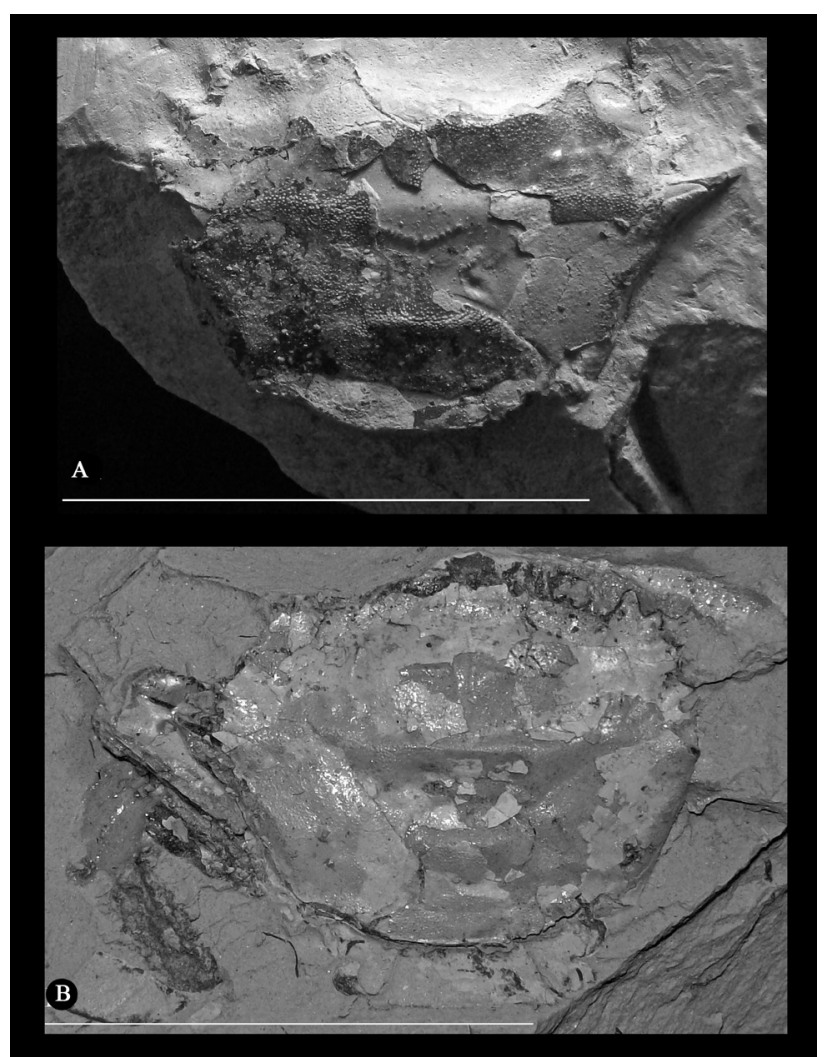

Figure 12. Bathynectes longipes (Risso, 1816). A) MUSNAF 7068, dorsal view. Scale bar: $40 \mathrm{~mm}$. B) MUSNAF 7069, dorsal view. Scale bar: $26.5 \mathrm{~mm}$.

Material and measurements: Three specimens in dorsal view (one carapace lacking the front, MUSNAF 7068 - wcxp: $40 \mathrm{~mm}$; one nearly complete flattened carapace, MUSNAF 7069 - lcxp: $20.5 \mathrm{~mm}$; wcxp: $26.5 \mathrm{~mm}$ (excluding epibranchial tooth); one fragmentary carapace, MUSNAF 7070 - not measurable).

Description: Subhexagonal carapace, with maximum width at level of epibranchial tooth; dorsal surface slightly convex longitudinally, slightly vaulted at anterior third; front and orbits poorly preserved, except for the prominent triangular outer orbital tooth; anterolateral margin convex, with four teeth, excluding outer orbital tooth; prominent, triangular first, second, and third teeth, anteriorly directed; sharp, spiniform fourth (epibranchial tooth), curved, directed laterally; posterolateral margin slightly concave, converging posteriorly, weak re-entrant of P5 about one-third of total length of posterolateral margin; straight posterior margin, slightly rimmed; dorsal regions poorly defined, cervical and brachiocardiac grooves not well marked; two small epigastric swellings present at the base of the front; large, swollen protogastric lobes with transverse ridges; mesogastric region not well marked; hepatic region slightly swollen; inflated metagastric region; depressed urogastric region; metagastric and urogastric regions separated by a pair of submedian gastric pits; well marked and continuous transverse ridge connecting both epibranchial teeth; slightly swollen epibranchial, mesobranchial, and metabranchial regions; large cardiac region, very swollen; intestinal region flat.

Discussion: The specimens have been compared with the genera of Polybiidae Ortmann, 1893 (sensu Schubart and Reuschel, 2009) and Bathynectes is the only genus in which to accommodate them, considering morphological affinities with the fossil and extant species: four anterolateral teeth (excluding the outer orbital tooth), a marked transverse ridge connecting the prominent epibranchial teeth, and a short cardiac ridge. The only fossil species known to date is B. muelleri Ossó and Stalennuy, 2011, from the Miocene of Ukraine (Ossó and Stalennuy, 2011). The Miocene species differs from the Early Pleistocene species (coralgal reefs the first, soft bottom the second) by two morphological characters of the carapace: indeed in $B$. muelleri, the transverse ridges of protogastric lobes are absent and the transverse ridge connecting both epibranchial teeth is weak and interrupted at the metagastric level, whereas in the Early Pleistocene species, the transverse ridges of protogastric lobes are present and the transverse ridge connecting both epibranchial teeth is well marked and continuous. As reported by Zariquey Álvarez (1968) and Falciai and Minervini (1992), two extant species of Bathynectes live in Mediterranean Sea, B. longipes (Risso, 1816) and B. maravigna (Prestandrea, 1839). The specimens are excluded from $B$. maravigna because the extant species has anterolateral teeth relatively longer and sharper, and the epibranchial tooth is extremely long and directed almost horizontally. We accommodate the specimens in $B$. longipes because they have the same size, and also triangular anterolateral teeth, moderately elongate epibranchial tooth, slightly curved forward, the two transverse ridges of the protogastric lobes, and the continuous and well-marked transverse ridge connecting both epibranchial teeth. Bathynectes longipes is reported herein for the first time from the fossil record, attesting that the environment of the extant Mediterranean species was colonized almost since the Early Pleistocene.

\section{Superfamily Xanthoidea MacLeay, 1838 Family Xantidae MacLeay, 1838 \\ Subfamily Euxanthinae Alcock, 1898 Genus Monodaeus Guinot, 1967}

Type species: Xanto couchii Couch, 1851, by original designation.

Fossil species: Monodaeus bortolottii Delle Cave, 1988.

\section{Monodaeus bortolottii Delle Cave, 1988}

Figure 13

Monodaeus bortolottii Delle Cave, 1988, p. 123-126, pl. 1 ( figs. 1, 2), pl. 2 ( figs. 1-5).

Monodaeus bortolottii De Angeli et al., 2009, p. 185, 195, fig. 16. - Pasini and Garassino, 2013 


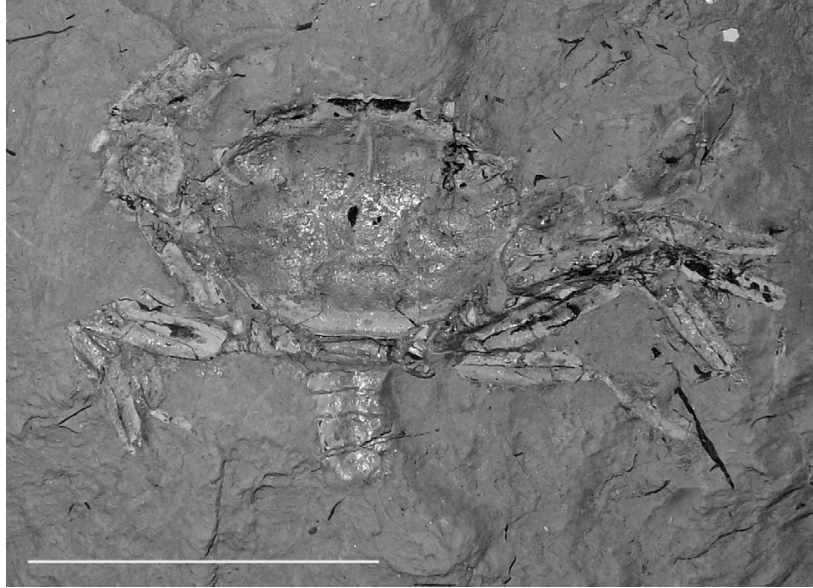

Figure 13. Monodaeus bortolottii Delle Cave, 1988, MUSNAF 7071, dorsal view. Scale bar: $16.5 \mathrm{~mm}$.

Material and measurements: One carapace threedimensionally preserved with counterpart (MUSNAF 7071 a, b - lcxp: $20 \mathrm{~mm}$; wcxp: $16.5 \mathrm{~mm}$ ).

Description: Suboctagonal carapace slightly convex, wider than long; straight front margin, with a weak median incision; short, convex anterolateral margin; long, convergent posterolateral margin; posterior margin straight medially and convex on margins with a granular ridge; dorsal region well marked by grooves, with wide, raised epigastric lobes; suboval protogastric regions well marked; subpentagonal mesogastric regions with narrow, elongate anterior process between protogastric regions; cardiac region well marked by branchiocardiac grooves; small hepatic regions poorly marked; wide branchial regions well marked.

Discussion: The specimen is assigned to Monodaeus bortolottii Delle Cave, 1988, already reported from the Pliocene of Volterra (Delle Cave, 1988) and Grosseto (De Angeli et al., 2009). Recently Pasini and Garassino (2013) reported this species from the Pliocene (Piacenzian) of Castellarano and Monticelli di Quattro Castella (Reggio Emilia, N Italy). The presence of this species from the Early Pleistocene clay sediments of Poggio i Sodi quarries increases the stratigraphical range of this species.

Superfamily Eriphioidea MacLeay, 1838

Family Eriphiidae MacLeay, 1838

Genus Eriphia Latreille, 1817

Type species: Cancer spinifrons Herbst, 1785, by subsequent designation by H. Milne Edwards (1842).

Fossil species: see Schweitzer et al. (2010).

Eriphia sp.

Figure 14

Material and measurements: One incomplete carapace

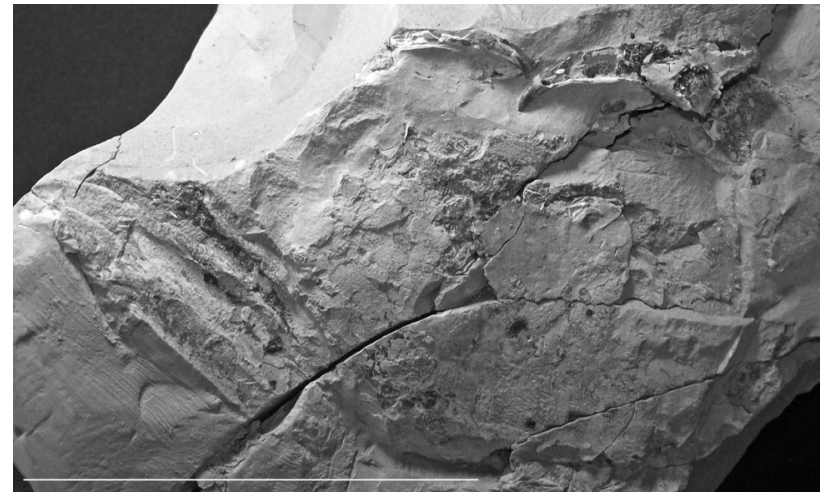

Figure 14. Eriphia sp., MUSNAF 7072, dorsal view. Scale bar: $72 \mathrm{~mm}$.

in dorsal view (MUSNAF 7072 - lcxp: 44 mm; wcxp: 72 $\mathrm{mm})$.

Discussion: The specimen consists in a dorsally compressed, crushed carapace and partial chelipeds. Unfortunately the anterolateral and frontal margins are poorly preserved and do not allow any specific comparison. We point out, however, that the general form of the carapace, preserving some spines along the anterolateral margins, the slightly granulate surface with the regions not well marked, the developed chelae, and the rounded globular carpus having some spines, resemble the general characters of Eriphia cocchi Ristori, 1886, already reported from the Pliocene of Lombardy (northern Italy) (Pasini and Garassino, 2011) and widespread in the Pliocene of Tuscany (Garassino et al., 2012).

$$
\begin{gathered}
\text { Superfamily Goneplacoidea MacLeay, } 1838 \\
\text { Family Goneplacidae MacLeay, } 1838 \\
\text { Subfamily Goneplacinae MacLeay, } 1838 \\
\text { Genus Goneplax Leach, } 1814
\end{gathered}
$$

Type species: Ocypoda bispinosa Lamarck, 1801, by original designation.

Fossil species: see Schweitzer et al. (2010).

Remark - Goneplax Leach, 1814 has been the subject of a recent review (see Garassino et al., 2013, in this volume).

Goneplax rhomboides (Linnaeus, 1758)

Cancer rhomboides Linnaeus, 1758, p. 626. Goneplax rhomboides Heller, 1863, p. 104, pl. 3, figs. 3, 4. - Ristori, 1886, p. 111-113. - Zariquiey Álvarez, 1968, p. 414-416, fig. 138 a, b. - Rice and Chapman, 1971, p. 336, 337, 339, figs. 5-7. - Falciai and Minervini, 1992, p. 238, pl. 17, fig. 1. - Karasawa and Kato, 2003, tab, 1, tab. 6. - Garassino and De Angeli, 2004, p. 44, 45, figs.

12-15. - Garassino et al., 2004, p. 274, 275, fig. 14. Castro, 2007, p. 686-690, 692, fig. 27. - Garassino et al., 2012, p. 45-47, 53, fig. 20 C, D. - Garassino et al., 2013.

Material and measurements: One specimen in dorsal 
view (MUSNAF 7073 - lcxp: $18.7 \mathrm{~mm}$; wcxp: $14 \mathrm{~mm}$ )

Discussion: According to Garassino et al. (2013) the main characters of the specimen are typical of $G$. rhomboides is known to date only in the fossil record of Italy from the Miocene to Pleistocene of Piedmont, Emilia Romagna, Tuscany, Lazio, and Sicily, as reported by many authors (for complete references see Garassino et al., 2013). This species is widespread in the eastern Atlantic, western Africa, and Mediterranean Sea, burrowing in sublittoral shallow muddy and sandy bottoms from a few meters to about $100 \mathrm{~m}$ depth (Falciai and Minervini, 1992; Zariquey Álvarez, 1968).

Genus Albaidaplax Garassino, Pasini and Castro, 2013

Type species: Albaidaplax ispalensis Garassino, Pasini and Castro, 2013, by monotypy.

Fossil species: Albaidaplax ispalensis Garassino, Pasini and Castro, 2013.

Albaidaplax ispalensis Garassino, Pasini and Castro, 2013 Figure 15

Material and measurements: One specimen in dorsal view (MUSNAF 7074 - lcxp: $17.6 \mathrm{~mm}$; wcxp: $14 \mathrm{~mm}$ ).

Description: Carapace transversely rectangular, slightly wider than long; straight front; front as wide as the orbits; inner edge of supraorbital margin distinct; wide, orbits expanded distally, with one short tooth on outer orbital angle; supraorbital margins gently sinuous, without fissures; anterolateral margins slightly convex, apparently toothless; long, gently rounded posterolateral margins, strongly converging posteriorly; long, straight posterior margin; deep gastric pits; smooth dorsal surface of carapace; slight subhorizontal ridge, moderately convex, all level of antero- posterolateral margins, without clear indication of regions; stout, heavy chelipeds (P1), with moderately long merus; subtriangular, spineless carpus; stout, globular palm; dactylus and index slender, as long as the propodus, with

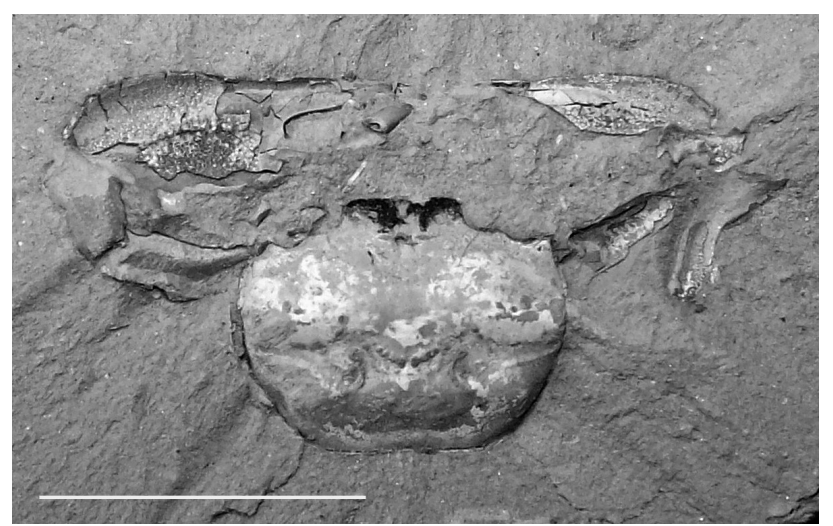

Figure 15. Albaidaplax ispalensis Garassino, Pasini and Castro, 2013, MUSNAF 7074, dorsal view. Scale bar: $17.6 \mathrm{~mm}$. toothless occlusal margin.

Discussion: The main morphological characters of the carapace, such as the shape, the wide orbits gently expanded distally, with one short tooth on outer orbital angle, and the supraorbital margins gently sinuous, are shared with the representatives of Albaidaplax, recently erected by Garassino et al. (2013, see this volume), with the type species A. ispalensis Garassino, Pasini and Castro, 2013, from the Pliocene of Spain and Italy. As reported by Garassino et al. (2013) this species has the anterolateral margins with a short tooth, not visible in the specimen having anterolateral margins apparently toothless. Since this tooth is very small, probably the state of preservation of the specimen compromises its observation. This finding in the sediments of Poggio i Sodi the stratigraphical range of this genus to the Early Pleistocene.

6. Paleoenvironmental implications (A.B., R.B., F.F., A.G., M.H., G.P.)

The comparison between the calcareous nannofossil assemblages found in decapod samples and the new sampling data allow to date the decapods-rich fauna of Poggio i Sodi to the late Gelasian-early Calabrian interval. The monotonous clay sedimentation clearly indicates stable environmental conditions through time. The sedimentological data highlight a very low energy, distal and relatively deep offshore environment. The presence, in assemblage, of benthic foraminifera and ostracods living in bathyal environment reinforces the sedimentological evidences, and a 200-300 m depth is reliable. In fact, these data only partially agree with the depth record, inferred in the literature, for described crustaceans. Decapod fauna presented herein consists of several taxa that can be considered as typical inhabitants of cool deep-water environment. The callianassid Bathycalliax has so far been known only from chemoautotrophic communities of the deep sea, approximately $625 \mathrm{~m}$ (Sakai and Türkay, 1999). Similarly, the presence of Lysirude, Retropluma, and isopod crustacean Palaega sismondai Ristori, 1891, can be considered as indicating deep, soft bottoms. Moreover, also the extant Nephrops norvegicus is recorded from deepwaters in the Mediterranean area living from 20 to $800 \mathrm{~m}$ on muddy bottoms in which it digs its burrows (Holthuis, 1991). Concerning Bathynectes, as reported by Politou et al. (2005) and Ossó and Stalennuy (2011) stated that the extant species inhabit soft, deep bottoms of the Mediterranean basin and the Atlantic Ocean, living from $90 \mathrm{~m}$ to $620 \mathrm{~m}$ (B. longipes), and from $322 \mathrm{~m}$ to $1003 \mathrm{~m}$ (B. maravigna). Moreover, the same taxa (i.e. Nephrops, Retropluma, Bathynectes, Goneplax, Lobocarcinus) are also reported as cool-water inhabitants (Zariquey Álvarez, 1968; Holthuis, 1991; Sakai and Türkay, 1999).

The foraminifera and ostracod assemblages allow indicate an upper bathyal environment, rich in nutrients, 
with fresh and low oxygenated condition at the sea floor. Thus, the occurrence of this unusual and extremely rich decapod fauna in the Poggio i Sodi area seems to be influenced by complex paleoenvironmental factors, and not exclusively by water depth. Cool water conditions at the sea floor, clayey soft bottom, nutrients and very low environmental energy and sedimentation rate, promoted the development of the rich decapod community, at least during Early Pleistocene.

\section{Acknowledgements}

We wish to thank F. Pizzolato (Arezzo), M. Cresti, A. Petri and P. Frediani of the Gruppo Paleontologico "C. De Giuli", Castelfiorentino (Firenze), for useful information and suggestion of Cava I Sodi quarries; A. De Angeli, Associazione degli Amici "Museo Civico G. Zannato", Montecchio Maggiore (Vicenza), for useful advice about systematics of some groups of crabs; G. Manganelli, Dipartimento Scienze Ambientali (UNISIENA) and F. Farsi, Sezione Geologica, Museo di Storia Naturale dell'Accademia dei Fisiocritici, Siena, Italy, for permission to study the specimens; F. J. Vega, Instituto de Geología, Universidad Nacional Autónoma de México, Ciudad Universitaria, Coyoacán, México, and an anonymous referee, for the critical reading of the manuscript and the careful review.

\section{References}

AAVV, in press, CARG - Foglio 297 "Asciano". ISPRA, Roma.

Alcock, A., 1898, Materials for a carcinological fauna of India. No. 3. The Brachyura Cyclometopa. Part I. The family Xanthidae: Journal of the Asiatic Society of Bengal, 67(1), 67-233.

Alcock, A., Anderson, A.R.J., 1894, Illustrations of the Zoology of the Royal Indian Marine Survey Ship Investigator, under the command of Commander T.H. Heming, R.N. Published under the Authority of Captain W. S. Goodridge, R.N., C.I.E. Director of the Royal Indian Marine: Crustacea Calcutta, India, Office of the Superintendent of Government Printing.

Aruta, G., Borgia, A., Bruni, P., Cecchi, G., Cipriani, N., Tredici, Y., 2004, Pliocene and Pleistocene unconformity bounded stratigraphic units (UBSU) in Val di Chiana, in: Morini, D., Bruni, P. (eds.), The "Regione Toscana" project of geological mapping, Firenze, 133-136.

Baba, K., MacPherson, E., Poore, G.C.B., Ahyong, S.T., Bermudez, A., Cabezas, P., Lin, C.-W., Nizinski, M., Rodrigues, C., Schnabel, K. E., 2008, Catalogue of squat lobsters of the world (Crustacea: Decapoda: Anomura - families Chirostylidae, Galatheidae and Kiwaidae): Zootaxa, 1905, 1-220.

Baldanza, A., Bizzarri, R., Hepach, H., 2011, New biostratigraphic data from the Early Pleistocene tyrrhenian palaeocoast (western Umbria, central Italy): Geologia Croatica, 64(2), 133-142.

Beschin, C., Santi, L., 1997, Cancer sismondai Meyer (Crustacea, Decapoda) nelle argille plioceniche di Vignola e Marano sul Panaro (Modena): Studi e Ricerche-Associazione Amici del Museo Civico "G. Zannato", 1997, 11-16.

Beurlen, K., 1930, Vergleichende Stammesgeschichte, Grundlagen, Methoden, Probleme unter besonderer Berücksichtigung der höheren Krebse: Fortschritte in der Geologie und Paläontologie, 8, 317-586.
Beurlen, K., 1939, Neue Dekapoden-Krebse aus dem ungarischen Tertiär: Paläontologische Zeitschrift, 21, 135-161.

Bishop, G.A., Williams, A.B., 2000, Fossil crabs from Tepee Buttes, submarine deposits of the Late Cretaceous Pierre Shale, South Dakota and Colorado, United States of America: Journal of Crustacean Biology, 20 (Special Number 2), 286-300.

Bogi, C., Cauli, L., Pagli, F., 2002, Le Architectonicidae Gray J. E., 1840 del Pliocene toscano: Bollettino Malacologico, 38, 31-40.

Bonaduce, G., Barra, D., Aiello, G., 1999, The genus Henryhowella Puri, 1957 (Crustacea, Oastracoda) in the Atlantic and the Mediterranean from Miocene to recent: Bollettino della Società Paleontologica Italiana, 38(1), 59-72.

Bonfiglio, L., 1982, Strutture dell'esoscheletro di Cancer sismondai Meyer osservate al SEM: Bollettino della Società Paleontologica Italiaina, 21(1), 5-20.

Bonfiglio, L., Donadeo, G., 1982, Cancer sismondai Meyer nel Pliocene di Torre dell'Orso (Puglia): Atti della Società italiana di Scienze naturali e del Museo civico di Storia naturale in Milano, 123, 255-296.

Borradaile, L.A., 1903, On the classification of the Thalassinidea: The Annals and Magazine of Natural History, 7(12), 534-551.

Bossio, A., Costantini, A., Lazzarotto, A., Liotta, D., Mazzanti, R., Mazzei, R., Salvatorini, G., Sandrelli, F. 1993, Rassegna delle conoscenze sulla stratigrafia del Neoautoctono toscano: Memorie della Società Geologica Italiana, 49, 17-98.

Bouvier, E.-L., 1940, Décapodes marcheurs, in: Faune de France, 37, 1-404.

Campbell, K.A., 2006, Hydrocarbon seep and hydrothermal vent paleoenvironments and paleontology: past developments and future research directions: Palaeogeography, Palaeoclimatology, Palaeoecology, 232, 362-407.

Castro, P., 2007, A reappraisal of the family Goneplacidae MacLeay, 1838 (Crustacea, Decapoda, Brachyura) and revision of the subfamily Goneplacinae, with the description of 10 new genera and 18 new species: Zoosystema, 29(4), 609-774.

Cigala Fulgosi, F., Casati, S., Orlandini, A., Persico, D., 2009, A small fossil fish fauna, rich in Chlamydoselachus teeth, from the late Pliocene of Tuscany (Siena, central Italy): Cainozoic Research, 6 (1-2), 3-23.

Costantini, A., Decandia, F.A., Lazzarotto, A., Liotta, D., Mazzei, R., Pascucci, V., Salvatorini, G., Sandrelli, F., Barazzuoli, P., Dringoli, R., Ghetti, P., Mellini, M., Mocenni, B., Rigati, R., Salleolini, M., 2009, Note Illustrative della Carta Geologica d'Italia alla scala 1:50000 - Foglio 296 "Siena": Ispra, 134 p.

Couch, R.Q., 1851, Notice of a crustacean, new to Cornwall: Transactions of the Natural History and Antiquarian Society of Penzance, 2, 13-14.

Couffon, O., 1908, Sur quelques Crustacés des faluns de Touraine et d'Anjou: Feuille des Jeunes Naturalists, 39, 5.

Crema, C., 1895, Sopra alcuni Decapodi terziarii del Piemonte: Atti della Reale Accademia delle Scienze di Torino, 30, 664-681.

Dana, J.D., 1852, Conspectus Crustaceorum, \& Conspectus of the Crustacea of the Exploring Expedition under Capt. Wilkes, U.S.N. Macroura: Proceedings of the Academy of Natural Sciences of Philadelphia, 6, 10-28.

Davis, J.W., 1887, Note on a Fossil Species of Chlamydoselachus: Proceedings of the Yorkshire Geological and Polytechnic Society, 9, 392-393.

De Angeli, A., Garassino, A., 2006, Catalog and bibliography of fossil stomatopoda and decapoda from Italy: Memorie della Società italiana di Scienze naturali e del Museo civico di Storia naturale di Milano, 35(1), 3-96.

De Angeli, A., Garassino, A., Pasini, G., 2009, New reports of anomurans and brachyurans from Cenozoic of Tuscany (Italy): Atti della Società italiana di Scienze naturali e del Museo civico di Storia naturale in Milano, 150(2), 163-196.

De Angeli, A., Garassino, A., Pasini, G., 2011, Retropluma craverii (Crema, 1895) (Crustacea, Decapoda, Brachyura, Retroplumidae) from the Pliocene of Reggio Emilia (N Italy): Atti della Società italiana di Scienze naturali e del Museo civico di Storia naturale in Milano, 152(1), 37-44. 
De Grave, S., Pentcheff, N.D., Ahyong, S.T., Chan, T.-Y., Crandall, K.A., Dworschak, P.C., Felder, D.L., Feldmann, R.M., Fransen, C.H.J.M., Goulding, L.Y.D., Lemaitre, R., Low, M.E.Y., Martin, J.W., Ng, P.K.L., Schweitzer, C.E., Tan, S.H., Tshudy, D., Wetzer, R., 2009, A classification of living and fossil genera of decapod crustaceans: The Raffles Bulletin of Zoology, Supplements 21, 1-109.

De Haan, H.M., 1833-1849, Crustacea, in: von Siebold, P.F. (ed.), Faunas Japonica, sive Descriptio animalium, quae in itinere per Japoniam, jussu et auspiciis superiorum, qui summum in India Batavia imperium tenet, suscepto, annis $1823-1830$ collegit, notis, observationibus a adumbrationibus illustravit: J. Müller et Co., Lugduni Batavorum, 1-8, 1-243.

de Saint Laurent, M., 1979, Sur la classification et la phylogénie des Thalassinides: definitions de la superfamille des Axioidea, de la sous-famille des Thomassiniinae et de deux genres nouveaux (Crustacea, Decapoda): Comptes Rendus Hebdomadaires des Séances de l'Academie des Sciences, série D288(31), 1395-1397.

de Saint Laurent, M., 1980, Sur la classification et la phylogenie des Crustacés Décapodes brachyoures. I. Podotremata Guinot, 1977, et Eubrachyura sect. nov. : Comptes Rendus Hebdomadaires des Séances de l'Academie des Sciences, série D290, 1265-1268.

de Saint Laurent, M., 1989, La nouvelle famille des Retroplumoidea Gill, 1894 (Decapoda, Brachyura): systématique, affinities et évolution, in: Forest, J. (ed.), Résultats des Campagnes MUSORSTOM: 5, Mémoire du Musée National d'Histoire Naturelle, 44, 103-179.

Delle Cave, L., 1988, Monodaeus bortolottii, a new species of Brachyura (Crustacea, Decapoda) from the Pliocene of Tuscany (Italy): Bollettino della Società Paleontologica Italiana, 27(2), 123-127.

Desmarest, A.G., 1822, Les crustacés proprement dits, in: Brongniart, A., Desmarest, A.G. (eds.), Histoire naturelle des crustacés fossiles sous les rapports zoologiques et géologiques: Paris, F.G. Levrault, Libraire, 67-142.

Dunbar, G.B., Barrett, P.J., 2005, Estimating palaeobathymetry of wavegraded continental shelves from sediment texture: Sedimentology, 52(2), 253-270.

Fabricius, J.C., 1793, Entomologia sistematica emendata et aucta. Secundum classes, ordines, genera, species adjectis synonymis, locis, observationibus, descriptionibus: Hafniae, 2, 1-519.

Falciai, L., Minervini, R., 1992, Guida dei Crostacei Decapodi d'Europa: Roma, Muzzio Editore, $282 \mathrm{p}$.

Faranda, C., Gliozzi, E., 2008, The ostracod fauna of the Plio-Pleistocene Monte Mario succession (Roma, Italy): Bollettino della Società Paleontologica Italiana, 47(3), 215-267.

Feldmann, R.M., Tucker, A.B., Berglund, R.E., 1991, Fossil Crustaceans: Paleobathymetry of decapod crustaceans: Washington, National Geographic Research \& Exploration, 7, 352-363.

Fornaciari, A., Garassino, A., 1996, La specie Cancer sismondai Meyer, 1843 (Crustacea, Brachyura) nei depositi pleistocenici del fiume Enza (Parma, Italia). Atti XIII Convegno Società Paleontologica Italiana, 89-90.

Fowler, H.W., 1912, The Crustaea of New Jersey: Reports of the New Jersey Museum, 1911, 29-650.

Garassino, A, De Angeli, A., 2004, Decapod crustacean fauna from the Pliocene and Pleistocene of Arda, Stirone and Enza Rivers (Piacenza, Parma and Reggio Emilia Provinces, N Italy): Atti della Società italiana di Scienze naturali e del Museo civico di Storia naturale in Milano, 145, (1), 29-57.

Garassino, A., De Angeli, A., Gallo, L.M., Pasini, G., 2004, Brachyuran and anomuran fauna from the Cenozoic of Piedmont (NW Italy): Atti della Società Italiana di Scienze Naturali e del Museo Civico di Storia Naturale di Milano, 145(2), 251-281.

Garassino, A., Fornaciari, A., 2000, Cancer sismondai Meyer, 1843 (Crustacea, Brachyura) in the Pleistocene deposists of Enza River (Parma, Italy): Studi e Ricerche, Associazione Amici del Museo Museo Civico "G. Zannato", $1^{\text {st }}$ Workshop on Mesozoic and Tertiary decapod crustaceans, 29-30.

Garassino, A., Pasini, G., De Angeli, A., Charbonnier, S., Famiani, F., Baldanza, A., Bizzarri, R., 2012, The decapod community from the Early Pliocene (Zanclean) of "La Serra" quarry (San Miniato, central Italy): sedimentology, systematics, and palaeoenvironmental implications: Annales de Paléontologie, 98, 1-61.

Garassino, A., Pasini, G., Marini, F., 2012, Bathypluma pliocenica n. sp. (Decapoda, Brachyura, Retroplumidae) from the Zanclean (Early Pliocene) of Volterra (Pisa, Toscana, Italy): Atti della Società italiana di Scienze naturali e del Museo civico di Storia naturale in Milano, 153(1), 63-69.

Garassino, A., Pasini, G., 2013, Calappa granulata (Linnaeus, 1758) (Crustacea, Decapoda, Brachyura, Calappidae) and Astiplax n. gen., n. sp. (Crustacea, Decapoda, Brachyura, Goneplacidae) from the Asti sand Fm. (Late Pliocene) of S. Pietro (Asti, Piemonte, NW Italy): Boletín de la Sociedad Geológica Mexicana, 65(2), 329-334.

Garassino, A., Pasini, G., Castro, P., 2013, Revision of the fossil species of Goneplax Leach, 1814 (Crustacea, Decapoda, Brachyura, Goneplacidae): Boletín de la Sociedad Geológica Mexicana, 65(2), 355-368.

Gemmellaro, M., 1914, Crostacei e pesci fossili del "Piano Siciliano" dei dintorni di Palermo: Giornale di Scienze Naturali ed Economiche di Palermo, 30, 73-94.

Gill, T., 1894, A new bassalian type of crabs: American Naturalist, 28, 1043-1045.

Goeke, G.D., 1986, Decapod Crustacea: Raninidae, in: Forest, J. (ed.), Résultats des Campagnes MUSORTOM I et II, Philippines 2: Mémoires du Muséum national d'Histoire naturelle, 133, 205-228.

Guinot, D., 1967, Recherches preliminaries sur les groupements naturels chez les Crustacés Décapodes Brachyoures, II: Les anciens genres Micropanope Stimpson et Medaeus Dana: Bulletin du Muséum national d'Histoire naturelle, 39, 345-374.

Guinot, D., 1977, Propositions pour une nouvelle classification des Crustacés Décapodes Brachyoures: Comptes Rendus des Seances Hebdomadaires de l'Academie des Sciences, D285, 1049-1052.

Guinot, D., 1993, Données nouvelles sur les Ranonoidea De Haan, 1841 (Crustacea, Decapoda, Brachyura, Podotremata): Comptes Rendus de l'Academie des Sciences, III, 316(11), 1324-1331.

Heller, C., 1863, Die Crustaceen des südlichen Europa. Crustacea Podophthalmia. Mit einer Übersicht über die horizontale Verbreitung sämtlicher europäischer Arten: Wien, Wilhelm Braumüller, 336 p.

Herbst, J.F.W., 1782-1804, Versuch einer Naturgeschichte der Krabben und Krebse nebst einer Systematischen Beschreibung ihrer Verschiedemen Arten: Berlin, Gottlieb August Lange; Zürich, J. C. Fuessly, 515 p.

Holthuis, L.B., 1991, FAO species catalogue. Marine lobsters of the world: an annotated and illustrated catalogue of species of interest to fisheries known to date: Rome, Food and Agriculture Organitazion of the United Nations Fisheries Synopsis, 125, 13, 1-276.

Hyžný, M., Müller, P.M., 2012, The fossil record of Glypturus Stimpson, 1866 (Crustacea, Decapoda, Axiidea, Callianassidae) revisited, with notes on palaeoecology and palaeobiogeography: Palaeontology, 55(5), 967-993.

Hyžný, M., Schlögl, J., 2011, An early Miocene deep-water decapod crustacean faunule from the Vienna Basin (Western Carpathians, Slovakia): Palaeontology, 54(2), 323-349.

Johnson, J.Y., 1861, Description of a new species of Cancer obtained at Madeira: Proceedings of the Scientific Meetings of the Zoological Society of London, 16, 240-242.

Kaiho, K., 1999, Effect of organic carbon flux and dissolved oxygen on the benthic foraminiferal oxygen index (BFOI): Marine Micropaleontology, 37, 67-76.

Karasawa, H., 1991, Decapod Crustaceans from the Miocene Mizunami Group, Central Japan Part 3. Decapod Crustacean Assemblage and Paleoecology, with Descriptions of Two Species: Bulletin of the Mizunami Fossil Museum, 18, 1-18.

Karasawa, H., 1993, Cenozoic decapod Crustacea from southwest Japan: Bulletin of the Mizunami Fossil Museum, 20, 1-92.

Karasawa, H., 2011, New axiidean Decapoda from the Albian (Lower Cretaceous) chemosynthetic community of Hokkaido, Japan: Bulletin of the Mizunami Fossil Museum, 37, 27-29. 
Karasawa, H., Kato, H., 2003, The family Goneplacidae MacLeay, 1838 (Crustacea: Decapoda: Brachyura): systematics, phylogeny, and fossil records: Paleontological Research, 7(2), 129-151.

Kato, H., 1996, Miocene decapod crustacea from the Chichibu Basin, Central Japan: Transactions and Proceedings of the Palaeontological Society of Japan, new series, 183, 500-521.

Lamarck, J.B.P.A., 1801, Systéme des animaux sans vertébres ou Tableau général des classes, des ordres et des genres de ces animaux; Présentant leurs caractères essentiels et leur distribution, d'après la considération de leurs rapports naturels et de leur organisation, et suivant l'arrangement établi dans les galeries du Muséum d'Hist. Naturelle, parmi leurs dépouilles conservées; Précédé du discours d'ouverture du Cours de Zoologie donné dans le Muséum National d'Histoire Naturelle l'an 8 de la République: Paris, Déterville, 432 p.

Latreille, P.A., 1802, Histoire naturelle, générale et particulière des Crustacés et des Insectes. Ouvrage faisant suite à l'Histoire naturelle, générale et particulière, composée par Leclerc de Buffon, et rédigée par C.S. Sonini, membre de plusieurs sociétés savantes. Famille naturelles des genres: Paris, Dufart, 3, 1-467.

Latreille, P.A., 1810, Considération générales sur l'Ordre naturel des Animaux composant les Classes des Crustacés, des Arachnides et des Insectes; avec un tableau Méthodique de leurs genres, disposes en familles, Paris, $144 \mathrm{p}$.

Latreille, P.A., 1817, Les Crustacés, les Arachnides et les Insectes, in: Cuvier, G., Le régne animal distribué d'aprés son organisation, pour servir de base à l'histoire naturelle des animaux et d'introduction à l'anatomie comparée, 3, 1-653.

Leach, W.E., 1813-1815, Crustaceology, in: Webster, D., The Edinburgh Encyclopedia: Edinburgh, Balfour, 7, 385-437, 765-766.

Lebour, M.L., 1928, Larval stages of the Plymouth Brachyura: Proceedings of the Zoological Society of London, 1928, 473-560.

Lebour, M.L., 1931, Further notes on larval Brachyura: Proceedings of the Zoological Society of London, 1931, 93-96.

Linnaeus, C., 1758, Systema Naturae per Regna Tria Naturae, Secundum Classes, Ordines, Genera, Species, cum Characteribus, Differentiis, Synonymis, Locis, 10(1), 1-824.

Linnaeus, C., 1761, Fauna Suecica sistens Animalia Sueciae Regni: Mammalia, Aves, Amphibia, Pisces, Insecta, Vermes. Distributa per Classes, Ordines, Genera, Species, cum Differentiis Specierum, Synonymis Auctorum, Nominibus Incolarum, Locis Natalium, Descriptionibus Insectorum: Stockholmiae, L. Salvii, 578 p.

Lörenthey, I., 1909, Beiträge zur Tertiären Dekapodenfauna Sardiniens: Mathematische und Naturwissenschaftlichen Berichte aus Ungarn, 24, 202-259.

MacLeay, W.S., 1838, Illustrations of the Annulosa of South Africa; being a portion of objects of natural history chiefly collected during an expedition into the interior of South Africa, under the direction of Dr. Andrew Smith, in the years 1834, 1835, and 1836; fitted out by "The Cape of Good Hope Association for exploring Central Africa": Illustrations of the zoology of South Africa (Invertebrate), $75 \mathrm{p}$.

Man, J.G., de, 1905, Diagnoses of new species of macrurous decapod Crustacea from the "Siboga-Expedition": Tijdschrift der Nederlandsche Dierkundige Vereeniging, 9(3/4), 587-614.

Manganelli, G., Spadini, V., 2001, I molluschi marini pliocenici dei dintorni di Siena negli scritti di Carlo De Stefani e Carlo Pantanelli: Accademia dei Fisiocritici, Memorie, 8, 1-336.

Manganelli, G., Spadini, V., 2003, Gli squali del Pliocene Senese: Sistema Musei Senesi Quaderni Scientifico-Naturalistici, $80 \mathrm{p}$.

Martini, I.P., Sagri, M., 1993, Tectono-sedimentary characteristics of Late Miocene - Quaternary extensional basins of the North Appennines, Italy: Earth Science Review, 34, 197-223.

Maxia, C., 1946, Su alcuni crostacei dei dintorni di Roma: Bollettino del R. Ufficio geologico d'Italia, 69(7), 129-150.

Meneghini, G., 1857, Paléontologie de l'Ile de Sardaigne, in: La Marmora, A Voyage en Sardaigne: Turin, Imprimerie Royal, 1-584.

Milne Edwards, H., 1836-1844, Les Crustacés, in: Cuvier, G., Le Régne Animal distribué d'après son organisation, pour servir de base à l'anatomie comparée, 17, 1-278.
Milne-Edwards, A., 1864, Monographie des Crustacés de la famille Cancériens: Annales des Sciences Naturelles, Zoologie, 1, 31-88.

Milne-Edwards, A., 1880, Reports on the results of dredging under the supervision of Alexander Agassiz, in the Gulf of Mexico, and in the Caribbean Sea, 1877, '78, '79, by the U.S. Coast Survey Steamer "Blake", Lieut.-Commander C.D. Sigsbee, U.S.N., and Commander J.R. Bartlett, U.S.N., commanding. VIII. Études préliminaires sur les crustacés, 1ère partie: Bulletin of the Museum of Comparative Zoology Harvard, 8(1), 1-68.

Moissette, P., Müller, P., 1990, Crustacés decapodes des facies MarnoDiatomitiques du Messinien d'Iranie (Algerie Occidentale): Geobios, 23(6), 737-747.

Murray, J.W., 1991, Ecology and palaeoecology of benthic foraminifera: Longman Scientific and Technical, Wiley in Harlow, Essex, England, New York, $397 \mathrm{p}$.

Murray, J.W., 2006, Ecology and applications of benthic foraminifera. : Cambridge, Cambridge University Press, $426 \mathrm{p}$.

Ng, P.K.L., Guinot, D., Davie, P.J., 2008, Systema Brachyurorum: Part I. An annotated checklist of extant brachyuran crabs of the world: The Raffles Bulletin of Zoology, Supplement 17, 1-286.

Ngoc-Ho, N., 2003, European and Mediterranean Thalassinidea (Crustacea, Decapoda): Zoosystema, 25, 439-555.

Nobre, A., 1936, Crustáceos Decápodos e Stomatópodes Marinhos de Portugal, in: Fauna Marinha de Portugal, 4, 1-213.

Ortmann, A.E., 1893, Die Decapoden-Krebse des Strassburger Museums, mit besonderer Berücksichtigung der von Herrn Dr. Döderlein bei Japan und bei den Liu-Kiu Inseln gesammelten und zur Zeit im Strassburger Museum aufbewahrten Formen. VI Theil. Abtheilung: Brachyura (Brachyura genuine Boas). I. Unterabtheilung: Majoidea und Cancroidea, 1: Section Portuninea.: Zoologische Jahrbücher, Abteilung für Systematik, Geographie und Biologie der Thiere, 7(1), 23-88.

Ossó, A., Stalennuy, O., 2011, Description of the first fossil species of Bathynectes (Brachyura, Polybiidae) in the Badenian (middle Miocene) of the Medobory Hills (Ukraine, Central Parathetys), with remarks on its habitat ecology: Treballs del Museu de Geología de Barcelona, 18, 37-46.

Pasini, G., Garassino, A., 2011, Record of Eriphia cfr. E cocchi Ristori, 1886 (Crustacea, Brachyura, Eriphiidae) from the Early Pliocene of Cheglio (Taino, Varese) (N Italy): Atti della Società italiana di Scienze naturali e del Museo civico di Storia naturale in Milano, 152(2), 240-245.

Pasini, G., Garassino, A., 2013, Records of brachyuran crabs from the Pliocene (Piacenzian) of Reggio Emilia (Emilia Romagna, N Italy): Boletín de la Sociedad Geológica Mexicana, 65(2), 319-328.

Peckmann, J., Senowbari-Daryan, B., Birgel, D., Goedert, J.L., 2007, The crustacean ichnofossil Palaxius associated with callianassid body fossils in an Eocene methane-seep limestone, Humptulips Formation, Olympic Peninsula, Washington: Lethaia, 40, 273-280.

Politou, C.Y., Maiorano, P., D'Onghia, G., Mytilineou, C., 2005, Deepwater decapod crustacean fauna of the Eastern Ionian Sea: Belgian Journal of Zoology, 135(2), 235-241.

Prestandrea, N., 1839, Descrizione di due nuovi Crostacei dei Mari di Messina: Atti dell'Accademia Gioenia di Scienze Naturali di Catania, ser. $1,14,131-136$.

Raffi, I., 2002, Revision of the early-middle Pleistocene calcareous nannofossil biochronology $(1.75-0.85 \mathrm{Ma})$ : Marine Micropaleontology, 45, 25-55.

Rafinesque, C.S., 1815, Analyse de la nature, ou tableau de l'univers et des corps organisée: Palermo, L'imprimerie de Jean Barravecchia, 224 p.

Reuss, A.E., 1857, Zur Kenntnis fossiler Krabben: Sitzungsberichte der Akademie der Wissenschaften, 27, 161-166.

Reuss, A.E., 1858, Über kurzschwänzige Krebse im Jurakalke Mährens: Sitzungsberichte der Kaiserlichen Akademie der Wissenschaften, 31, 5-13.

Rice, A.L., Chapman, C.J., 1971, Observations on the burrows behaviour of two mud-dwelling decapod crustaceans, Nephrops norvegicus and Goneplax rhomboides: Marine Biology, 10, 330-342. 
Rio, D., Raffi, I., Villa, G., 1990, Pliocene-Pleistocene calcareous nannofossil distribution patterns in the Western Mediterranean, in: Kastens, K., Mascle, J. (eds.), Proceedings of the Ocean Drilling Project Science Results, 107, 513-533.

Risso, A., 1816, Histoire naturelle des Crustacés des environs de Nice. Paris, $175 \mathrm{p}$.

Ristori, G., 1886, I crostacei brachiuri e anomuri del Pliocene italiano: Bollettino della Società Geologica Italiana, 5, 93-128.

Ristori, G., 1891, Contributo alla fauna carcinologica del Pliocene italiano: Atti della Società Toscana di Scienze Naturali, 11, 3-18.

Sakai, K., 1970, A small collection of thalassinids from the waters around Tsushima Islands, Japan, including a new species of Callianassa (Crustacea, Anomura): Publications of the Seto Marine Biological Laboratory, 18, 37-47.

Sakai, K., 1999, Synopsis of the family Callianassidae, with keys to subfamilies, genera and species, and the description of new taxa (Crustacea: Decapoda: Thalassinidea): Zoologische Verhandelingen, 326, 1-152.

Sakai, K., Türkay, M., 1999, A new subfamily, Bathycalliacinae n. subfam., for Bathycalliax geomar n. gen., n. sp. from deep water cold seeps off Oregon, USA: Senckenbergiana biologica, 79, 203-209.

Samouelle, G., 1819, The entomologists' useful compendium; or an introduction to the knowledge of British insects, comprising the best means of obtaining and preserving them, and a description of the apparatus generally used; together with the genera of Linné, and modern methods of arranging the Classes Crustacea, Myriapoda, spiders, mites and insects, from their affinities and structure, according to the views of Dr. Leach. Also an explanation of the terms used in entomology; a calendar of the times of appearance and usual situations of near 3000 species of British Insects; with instructions for collecting and fitting up objects for the microscope: London, $496 \mathrm{p}$.

Schubart, C.D., Reuschel, S., 2009, A proposal for a new classification of Portunoidea and Cancroidea (Brachyura: Heterotremata) based on two independent molecular phylogenies, in: Martin J. W., Crandall K. A., Felder D. L., Decapod Crustacean Phylogenetics: Crustacean Issues, 18, 533-549.

Schweitzer, C.E., Feldmann, R.M., 2008, New Eocene hydrocarbon seep decapod crustacean (Anomura: Galatheidae: Shinkaiinae) and its paleobiology: Journal of Paleontology, 82, 1021-1029.

Schweitzer, C.E, Feldmann, R.M., Garassino, A., Karasawa, H., Schweigert, G., 2010, Systematic list of fossil decapod crustacean species: Crustaceana Monographs, 10, 1-222.

Sciuto, F., Rosso A., 2008, Distribution pattern of deep-water ostracod assemblages from Lower Pleistocene sediments from Furnari, Sicily: Bollettino della Società Paleontologica Italiana, 47(1), 33-43.

Serrano, F., Guerra-Merchán, A., 2012, Sea surface temperature for left coiling Neogloboquadrina population inhabiting the westernmost Mediterranean in the middle Pleistocene and the PleistocenePliocene transition: Geobios, 45, 231-240.

Sismonda, E., 1846, Descrizione dei pesci e dei crostacei fossili nel Piemonte: Memorie della Reale Accademia delle Scienze di Torino, series $2,10,1-89$.
Stefanelli, S., 2004, Cyclic changes in oxygenation based on foraminiferal microhabitats: Early-Middle Pleistocene, Lucania Basin (southern Italy): Journal of Micropalaeontology, 23, 81-95.

Stimpson, W., 1866, Description of new genera and species of macrurous Crustacea from the coasts of North America: Proceedings of the Chicago Academy of Sciences, 1, 46-48.

Stimpson, W., 1871, Preliminary Report on the Crustacea dredged in the Gulf Stream in the Straits of Florida, by L.F. de Pourtaleès, Assist. U.S. Coast Survey. Part I. Brachyura: Bulletin of the Museum of Comparative Zoology, 2, 109-160.

Takeda, M., Mizuno, Y., Yamaoka, M., 1986, Some fossil crustaceans from the Miocene Morozaki Group in the Chita peninsula, Central Japan: Kaseki no Tomo (Publication of the Tokai Fossil Society), 28, 12-22. [in Japanese]

Van Bakel, B.W.M., Guinot, D., Artal, P., Fraaije, R.H.B., Jagt J.W.M., 2012, A revision of the Palaeocorystoidea and the phylogeny of raninoidian crabs (Crustacea, Decapoda, Brachyura, Podotremata): Zootaxa, 3215, 1-216.

Van Straelen, V., 1927, Contribution à l'étude des Crustacés décapodes fossiles de la Péninsule Ibérique: Eos, 3, 79-94

Varola, A., 1981, Crostacei decapodi neogenici della Penisola Salentina (Italia): Thalassia Salentina, 1-37

Vía Boada, L., 1980, Ocypodoidea (Crustacés Décapodes) du Cénozoique Méditerranéen. Origine et evolution de cette superfamille: Annales de Paléontologie, Invertébrés, 66(1), 51-66.

Vía Boada, L., 1982, Nueva contribución al estudio paleontológico de la superfamilia Ocypodoidea (Crustáceos Decápodos): Boletín Geológico y Minero, 93(2), 115-119.

Vinassa de Regny, P.E., 1896, Platycarcinus sismondai del Museo Parmense e il Palaeocarpilius macrocheilus del Museo Pisano. : Rivista Italiana di Paleontologia, 2, 124-129.

Von Meyer, H., 1843, Briefliche Mitteilungen, in: Leonhardt und Bronn: Neues Jahrbuch für Mineralogie, Geognosie und Geologie, Stuttgart, C.F. Winter, 579-590.

Von Meyer, H., 1847, Cancer paulino-württembergensis aus einem jungern Kalkstein in Aegypten: Palaeontographica, 1, 91-98.

Weber, F., 1795, Nomenclator entomologicus secundum Entomologiam systematicam ill. Fabricii adjectis speciebus recens detectis et varietatibus: C.E. Bohn, Chilonii et Hamburgi, 171 p.

Zariquiey Álvarez, R., 1946, Crustáceos Decápodos Mediterráneos: Barcelona, Instituto Español de l'est Mediterráneo, 181 p.

Zariquiey Álvarez, R., 1968, Crustáceos Decápodos Ibéricos: Investigacíon Pesquera, 32, 1-499.

Manuscript received: November 25, 2012.

Corrected manuscript received: February 14, 2013.

Manuscript accepted: February 14, 2013. 